\title{
منهجية المقاصد والوسائل في الاجتهاد الفقهي
}
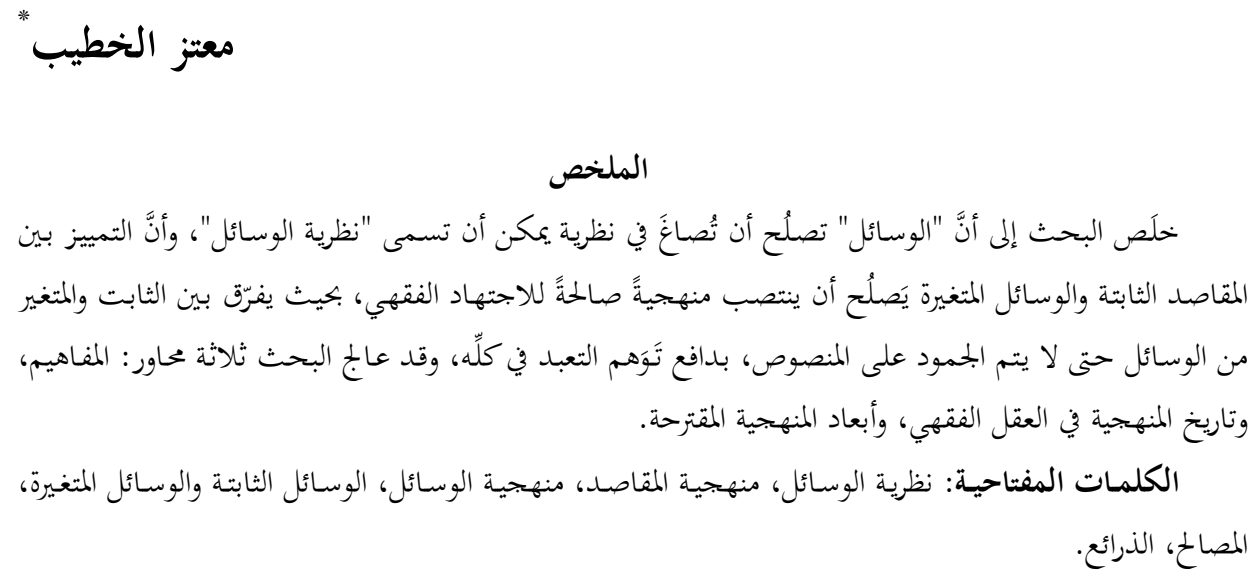

Methodology of Intents and Means in Jurisprudential Ijtihad

\begin{abstract}
The study discusses how the "means" may be articulated in a theory named "Theory of the Means". Distinguishing between the permanent objectives (maqasid) and changing means offers a legitimate methodology for jurisprudential ijtihad, which leads to a differentiation between the time-constant intent of this Law and the changing means. This methodology circumvents rigidity of scriptural texts under the illusion that texts are only rites for worship. The study addresses three themes: concepts; the history of methodology in the jurisprudential mind; and the dimensions and implications of the suggested methodology.
\end{abstract}

Keywords: Theory of Means, Methodology of Maqasid, Methodology of Means, constant means, and variable means, common good, pretext.

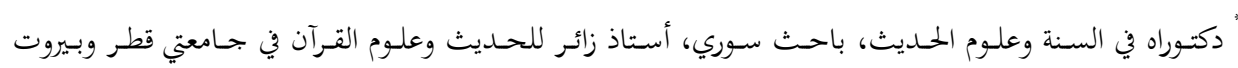

$$
\begin{aligned}
& \text { الإسلامية. البريد الإلكتروين: khateebm@aljazeera.net }
\end{aligned}
$$

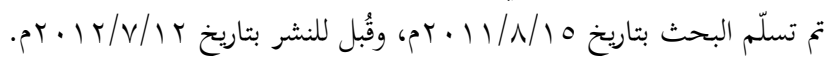




\section{مقدمة:}

شَغَل البحث في مقاصد الشريعة كثيراً من الاهتمام في الدراسات الفقهية والأصولية

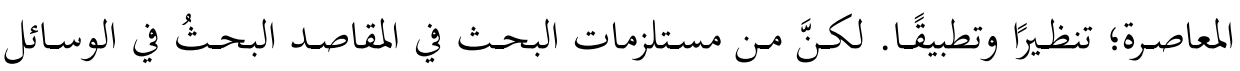

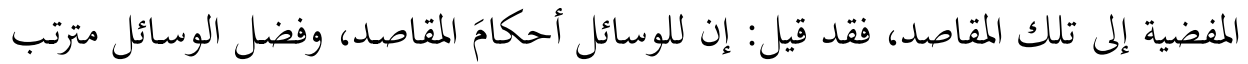
على فضل المقاصد، ولذلك تقوم بين الوسائل والمقاصد علائق مختلفة هي بحالُ اجتهادٍ،

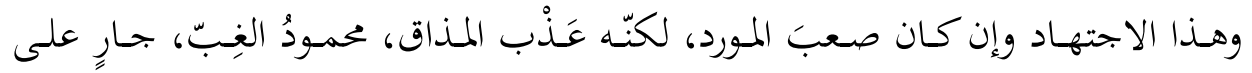
مقاصد الشريعة نفسها.

ومسن هـذا البـاب تحـدث علمـاء المقاصـد عـن مـآلات الأفعـال والذـرائع وغير ذلك،

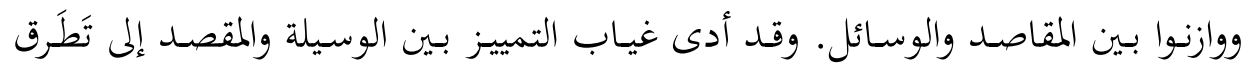

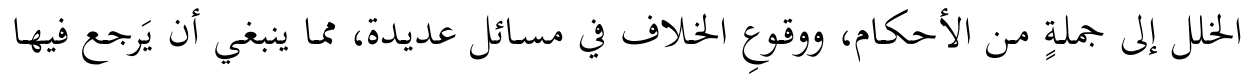
القول إلى منهجية التمييز بين الوسيلة والمقصسد. وعليه فبإن ضَبْط العلاقة بين الوسيلة

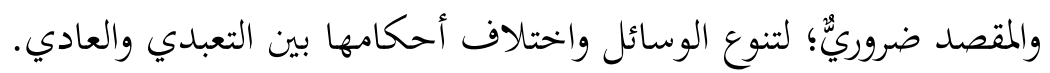
ومن أوجُهِهِ ضرورة التمييز بين الوسيلة والمقصد: تمحيصُ الثابت من المتغير، والمقصود لذاته من المقصود لغيره، والوسيلة المتمحضة من الوسيلة التي هي مقصدُ أيضًا، والوسيلة

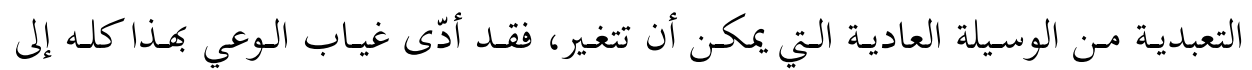

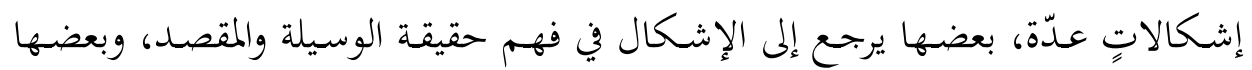
الآخر يرجع إلى الخلل في فهم وجه الوسيلة المنصوصة في السنة النبوية؛ هل هي من قبيل

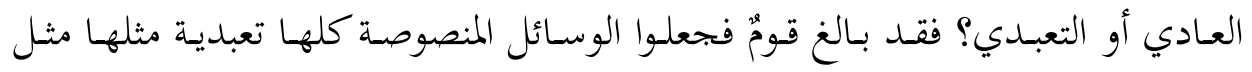

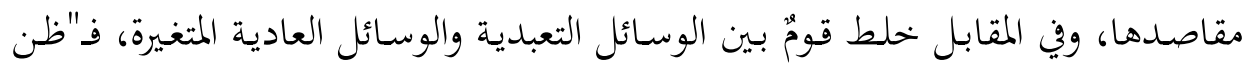

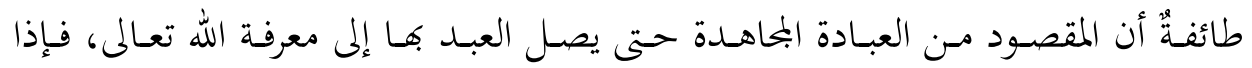
حصلت المعرفـة فقــ وصل، وبعـد الوصـول يستغني عـن الوسيلة والحيلة، فتركوا السعي

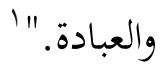


وإذا كانت دراسات المقاصد قد كَثُرت كثرة فائقة، فِإن فقه الوسائل مما يتطلب بحثًا وتحقيقًا؛ لأن فقه الوسائل قرينُ فقه المقاصد.

يتناول هذا البحث منهجية المقاصد والوسائل من خحلال ثلاثة محاور، يضبط أولُّا مفهوم المقاصد والوسائل، ويبحث ثانيها في تاريخ المنهجية في العقل الفقهي، في محاولة

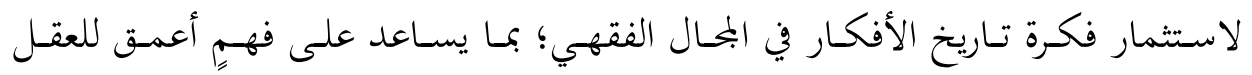

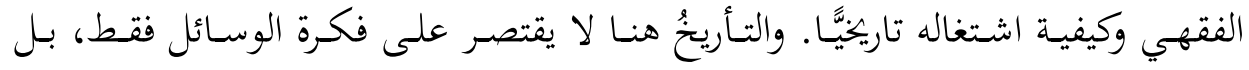

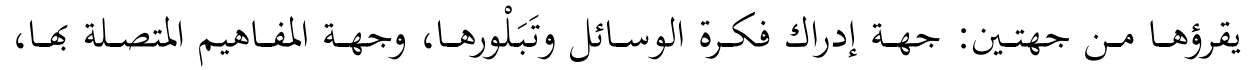

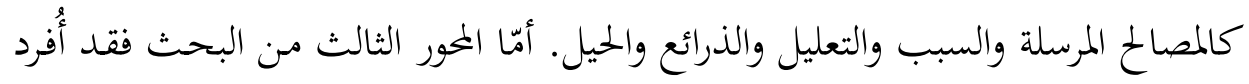

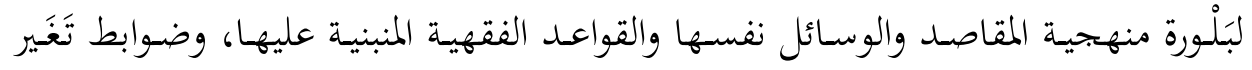
المنصوص منها، وأمثلتها، وغير ذلك.

وقد جاء الكالام على الوسائل من أئمة المقاصد في كتبهم، 'ُ وإن تفاوتوا في حجم

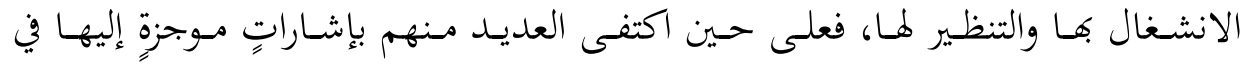

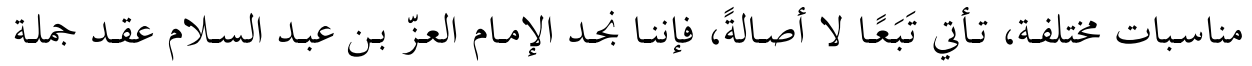

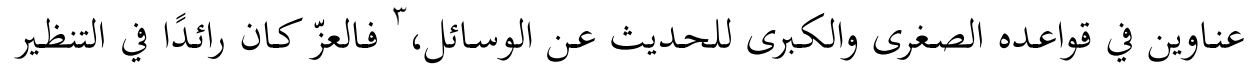

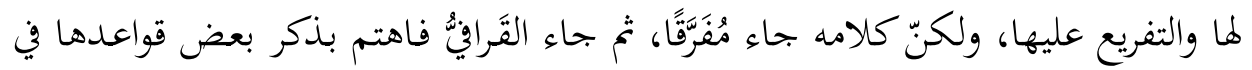
سياق انشـاله بالقواعـد الفقهيـة التي قصَّرت في ذكرهـا كتـبُ الأصـول، وكـلُّ مَن جـاء بعدهما هو عالةٌ عليهما، إمّا بتلخيص كلامهما، أو بتحريره، أو بالتفريع عليه والتمثيل له. ولكن، مُّا يُلاحَظ على تلك الكتابات:

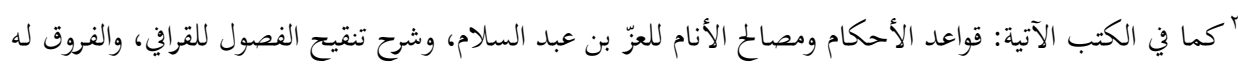

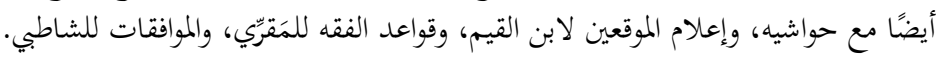

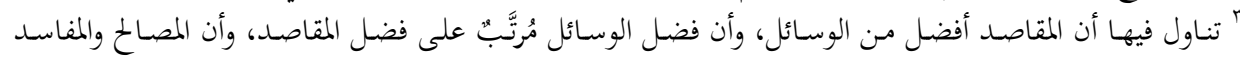

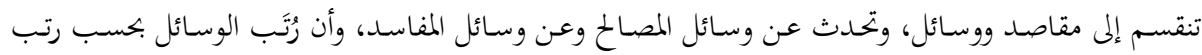

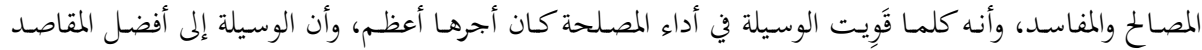

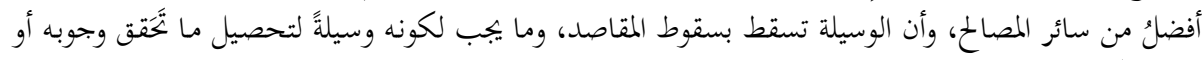

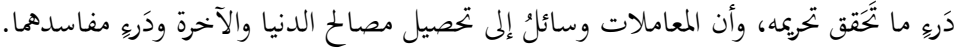




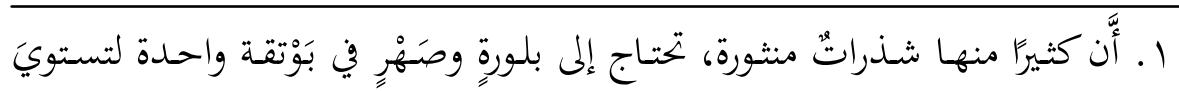
على منهجية متكاملة. r. أن أئمة المقاصد -وخحاصة العزّ بن عبد السلام الذي تميز بالتوسع في الحلديث

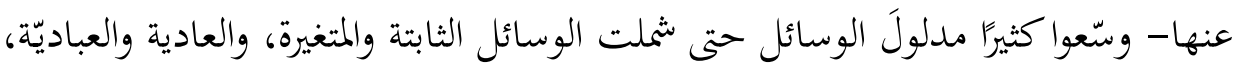

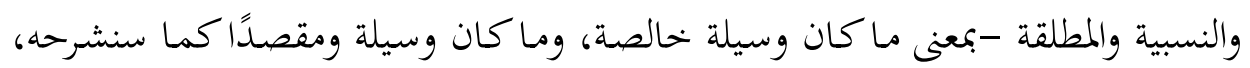
والوسائل التي هي مصالح، والوسائل التي هي مفاسد، إلى غير ذلك.

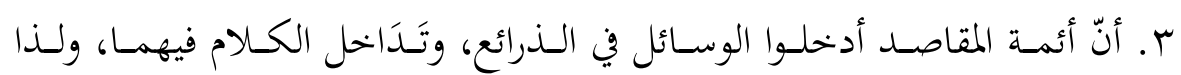

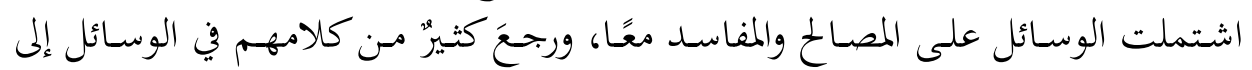

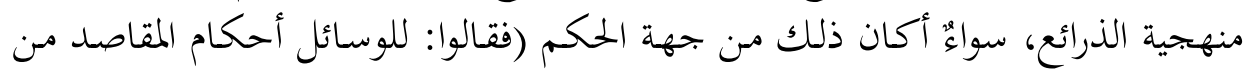

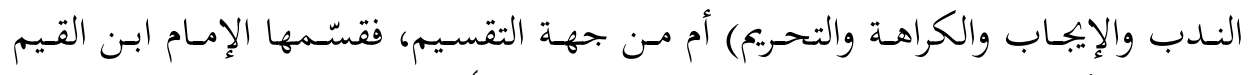

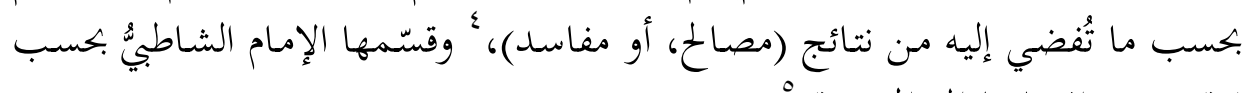
قوة ودرجة إفضائها إلى المفسدة.

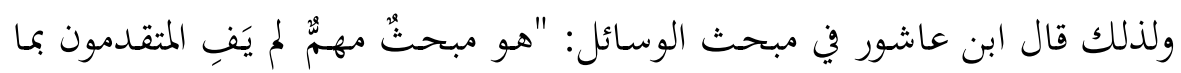

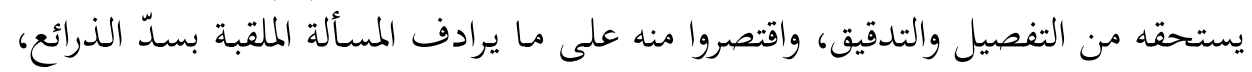

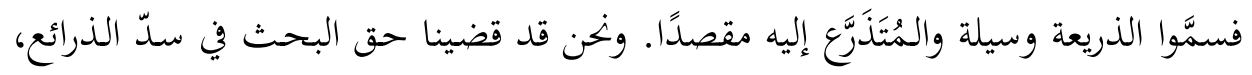

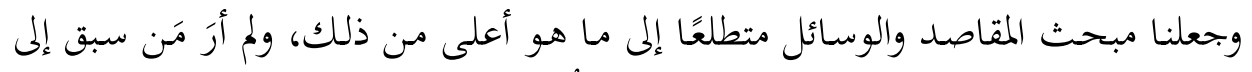

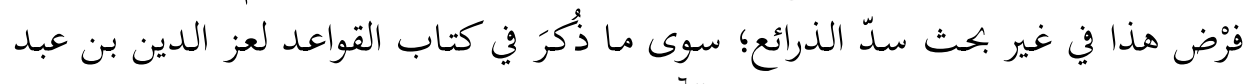

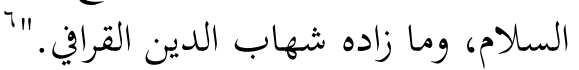

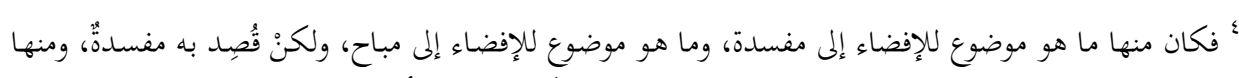

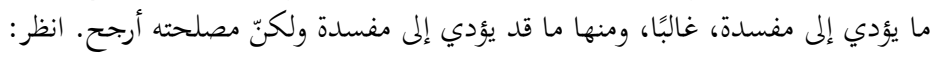

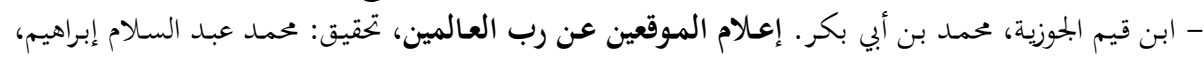

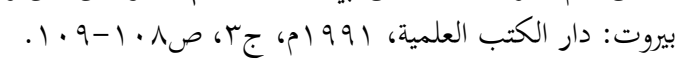

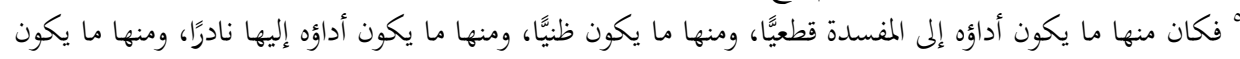

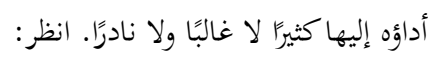

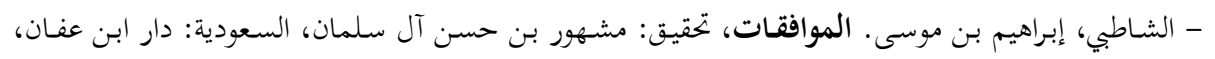

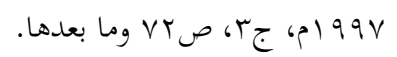

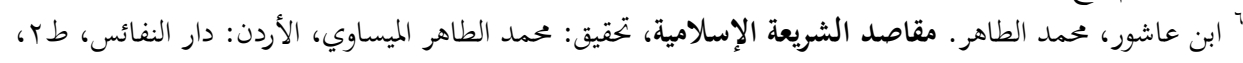

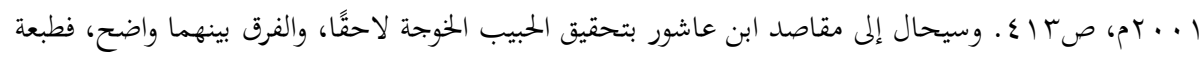

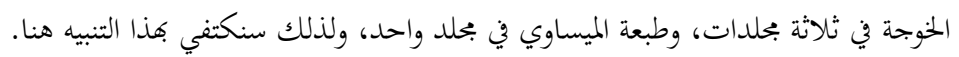


وأرى أن "الوسـائل" -علـى سـعة مــدلولاتها واسـتعمالاتحا وتطبيقاتهـا وقواعـدها

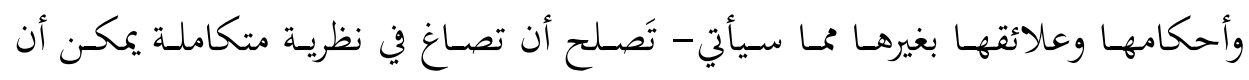

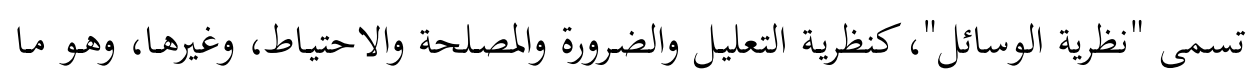

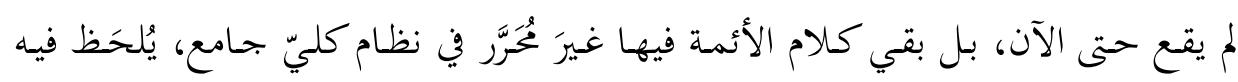

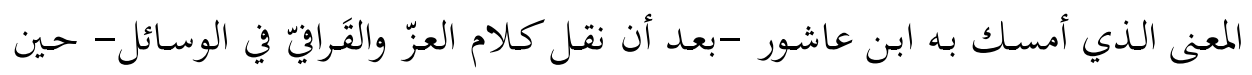

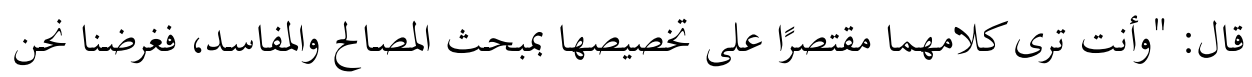

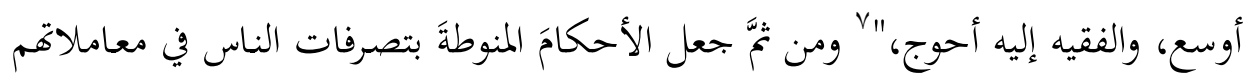

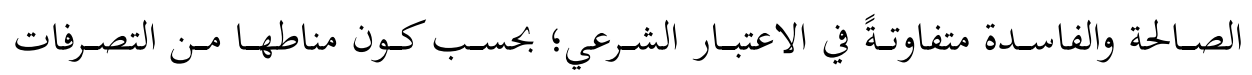
مقصدًا أو وسيلة في نظر الشرع أو في نظر الناس، وفصَّل في هاتين النقطتين. ولم تستوفِ مسألةُ الوسائل حظَّها من البحث اللائق بها من المعاصرين، فقد جرت الكتابات عنها في مسلكين:

المسلك الأول: التَّعرَُّ لما ضمن مبحثِ من كتاب، ^ويُلاحَظ على هذه الكتابات

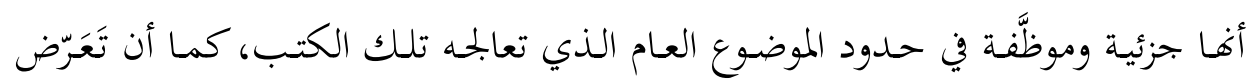

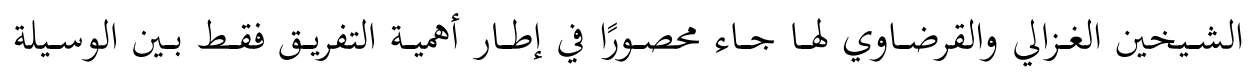
والمقصد أو الغاية مع التمثيل، دون معالجة أصولية للمسألة وضبطها بطريقة علمية وافية.

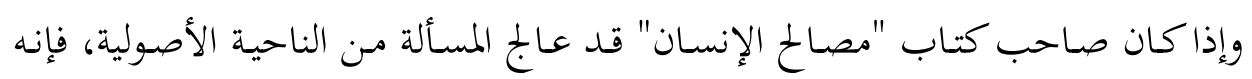

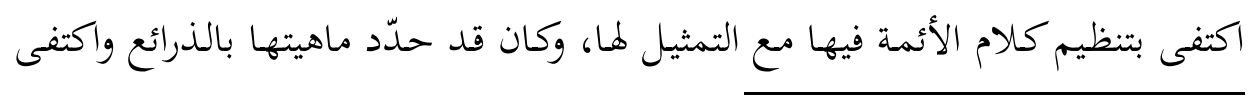

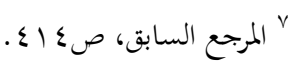

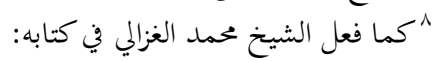

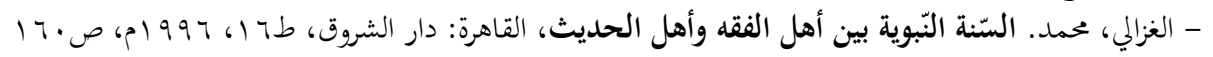

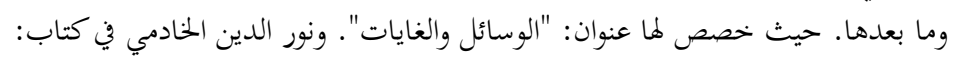

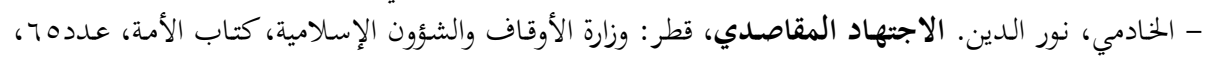

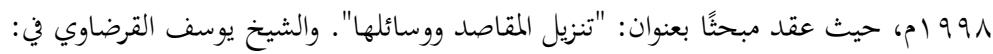

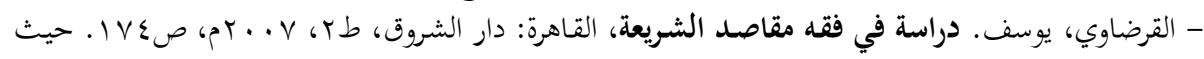

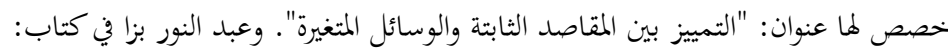

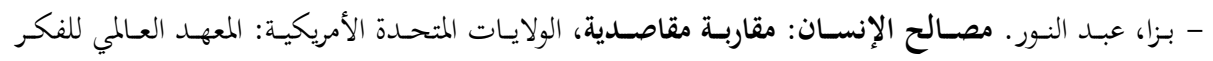

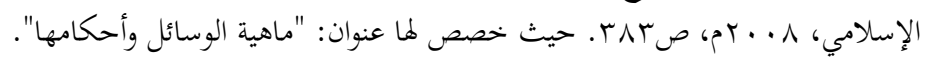




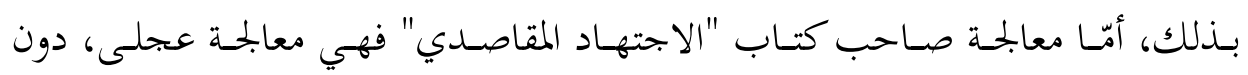
استيفاء أو تحرير؛ لأنه تَعَرّض لها عرَضًا.

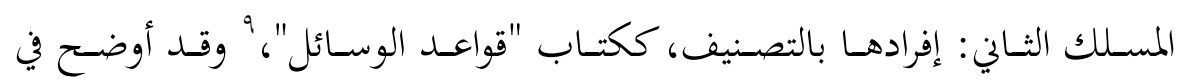

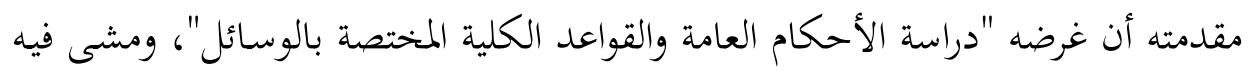

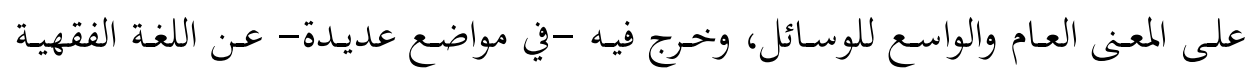

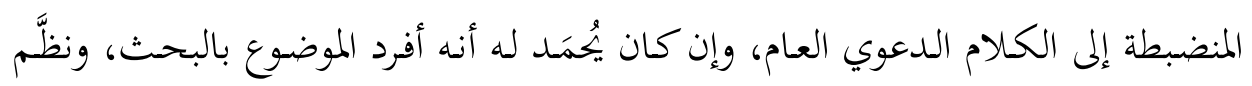

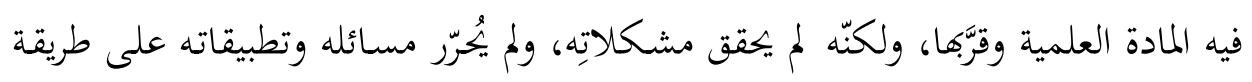
الفقهاء، فغَلَب عليه السرد والتقرير.

وككتاب "أحكام الوسائل بين الإلغاء والاعتبار: دراسة أصولية في ضوء المقاصد

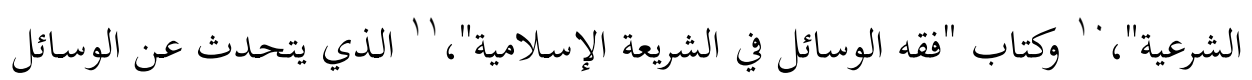

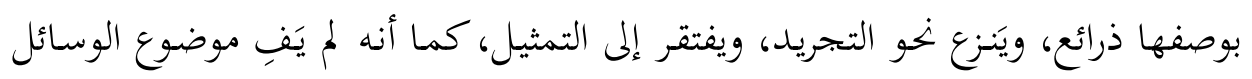
المتغيرة حقَّه.

وقـد تميّز بحثنـا -فيمـا أحسبـ- بتقيـيم بحمـل الكتابـات حول الوسـائل، وبتحرير

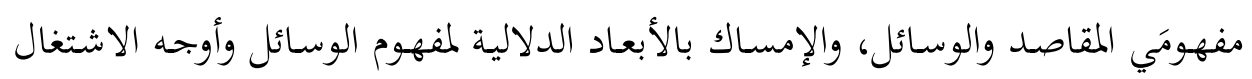

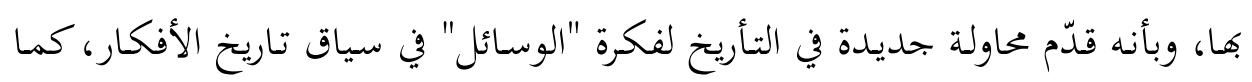

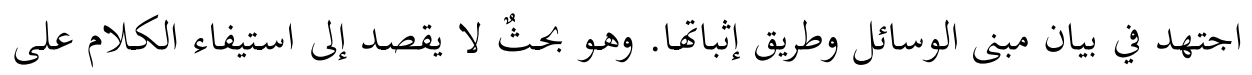

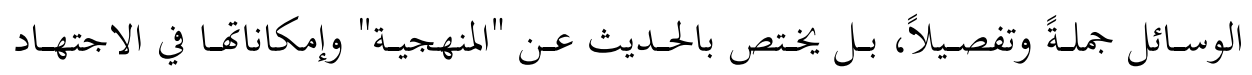

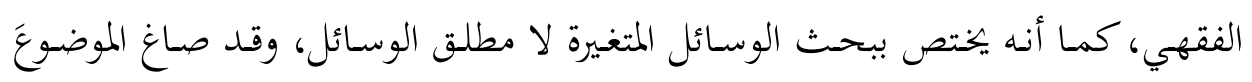
بوصفه منهجية متكاملة، ولم يتجاوز الصنعة الفقهية الأصولية ولغنَها.

9 مخدوم، مصطفى. قواعد الوسائل في الشريعة الإسلامية، الرياض: دار إشبيليا، 999 ام.

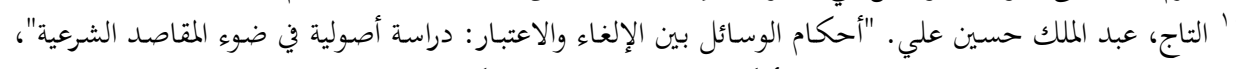

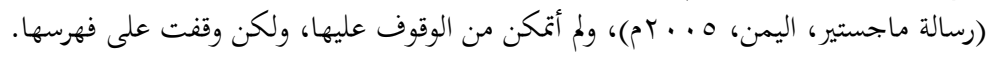

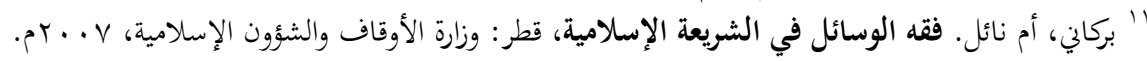




\section{أولاً: مفاهيم المقاصد والوسائل}

لفظا المقاصد والوسائل من الألفاظ اللغوية التي تتعدد معانيها، فلفظ المقاصد يرجعُ

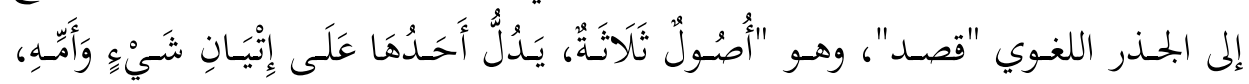

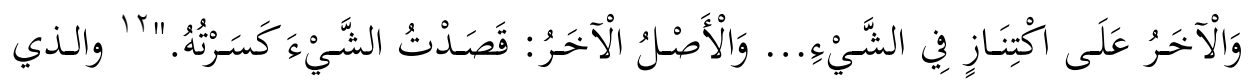

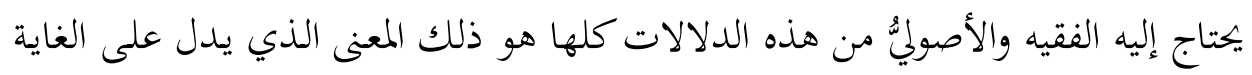

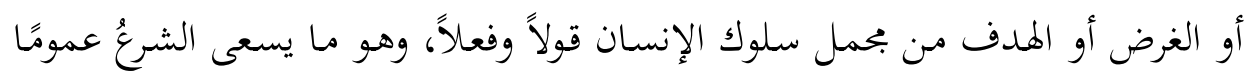

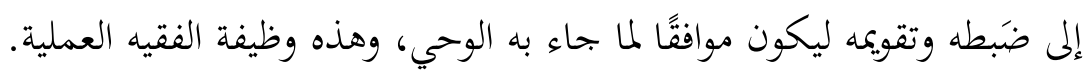
ولا يمكن تأسيس مفهوم الوسائل إلا على أساس مفهوم المقاصد حتى تكتمل أركان

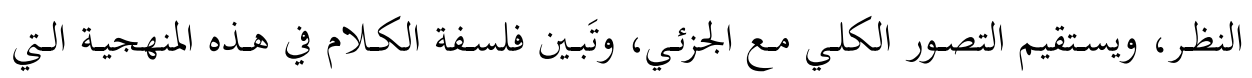

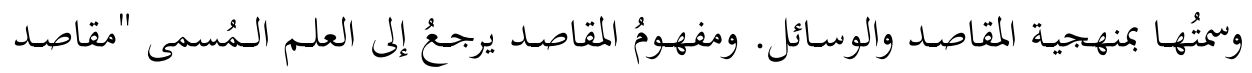

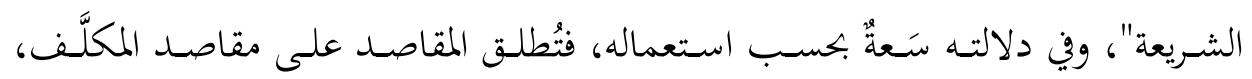

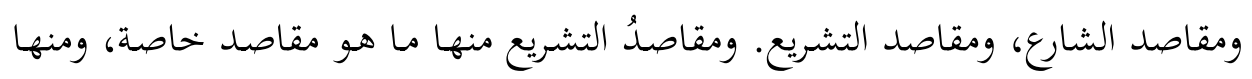

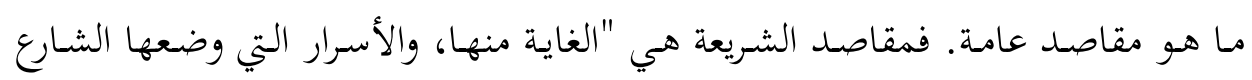

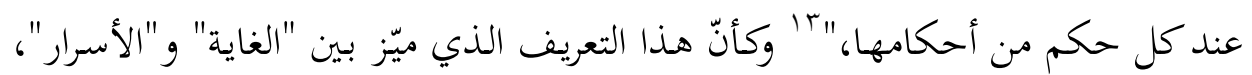

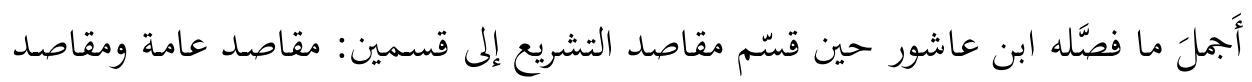

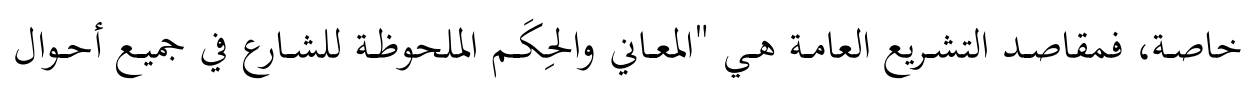

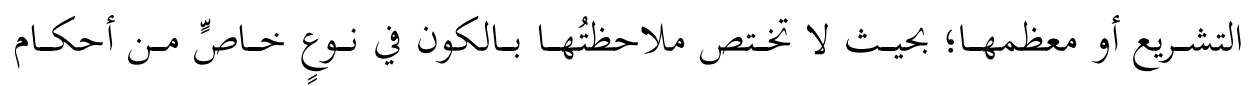

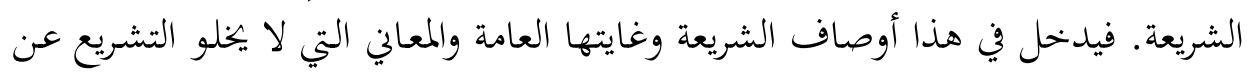

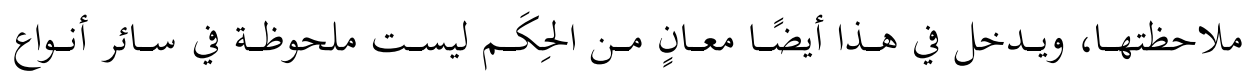

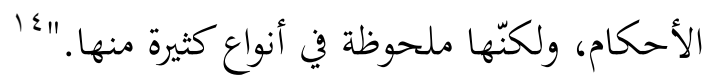

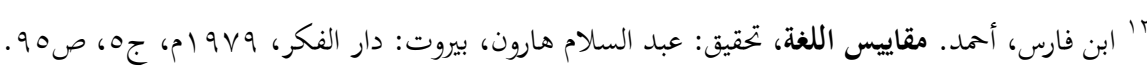

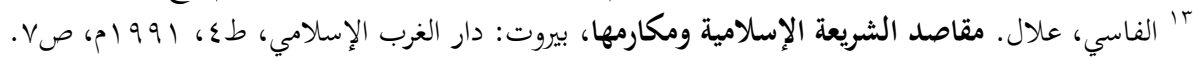

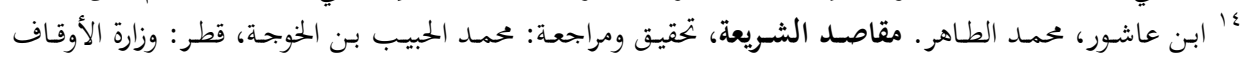

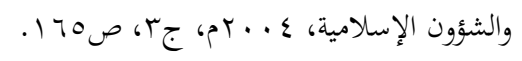


أمّا مقاصـُ التشـريع الخاصـة، فهي "الكيفيـات المقصـودة للشـارع لتحقيـق مقاصــ

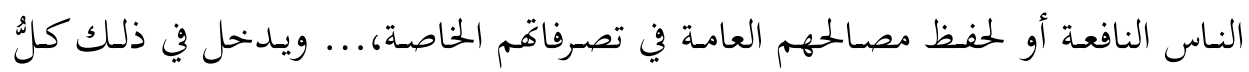
حكمـة روعيـت في تشـيع أحكام تصـرفات النـاس، مثل قصـد التوثق في عقـدة الرهن،

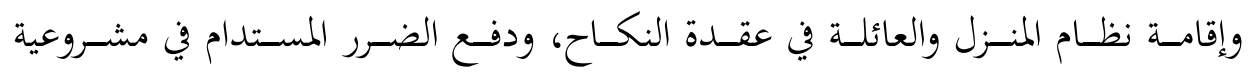
الطلاق.

"اولمقاصد التي يُنظر فيها قسمان: أحدهما يرجع إلى قصد الشارع، والآخر إلى قصد

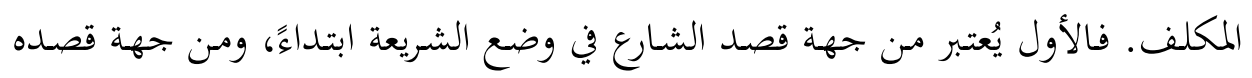
في وضعها للإفهام، ومسن جهة وضعها للتكليف بمقتضاها، ومن جهة قصدده في دخول

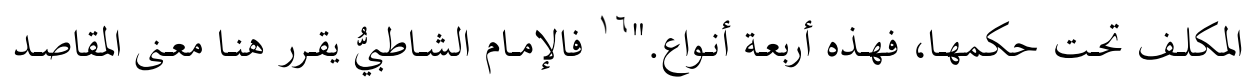

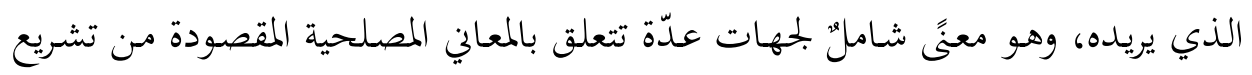
الأحكام، وبالمعاني الدلالية المقصودة من خطاب الشارع، وبإرادة التكليف بمقتضى الأمر والنهي، وبتحقيق الامتثال من أعيان المكلَّفين حتى تتحقق المصالح المقصودة؛ كلهّ بحسبه. والبحـث في المقاصسد تَوَجّهـ -في بحملـه- إلى الكشـف عـن المصـالح التي جـاءت

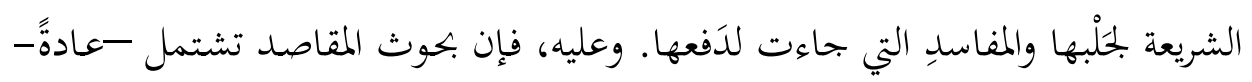

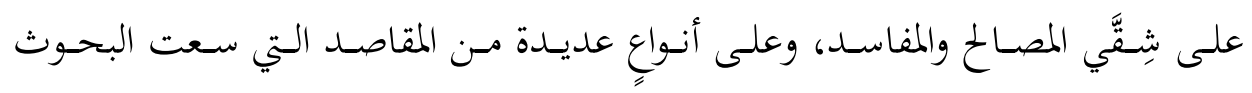

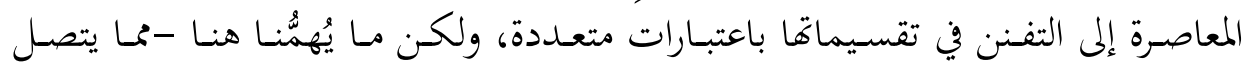

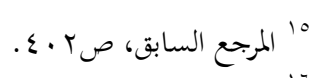

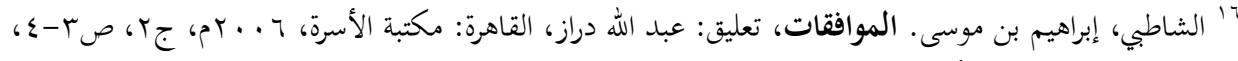

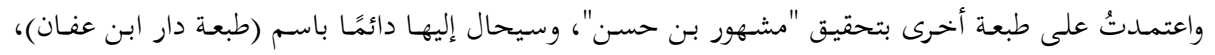
وانظر:

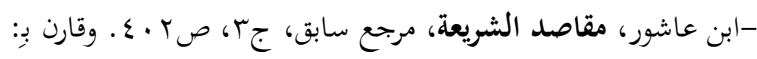

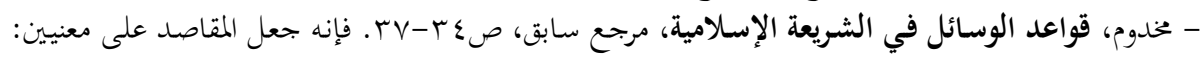

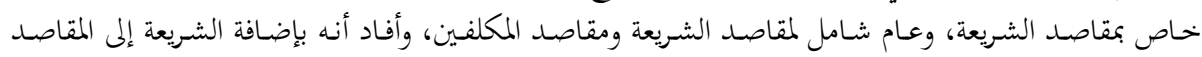

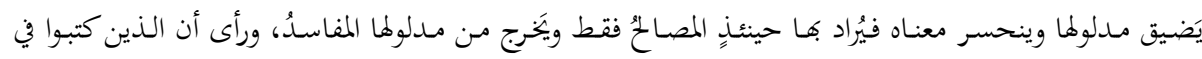

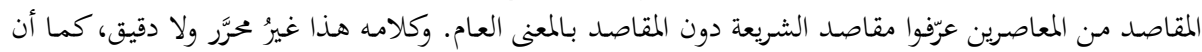

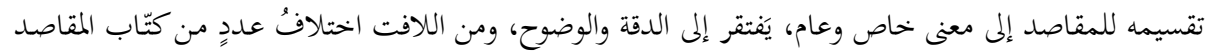


بتحديـد معنى الوسائل لاحقًّا- هو أن المقاصـد منهـا مـا هو عـام وكليّ يشـمل الشـريعة

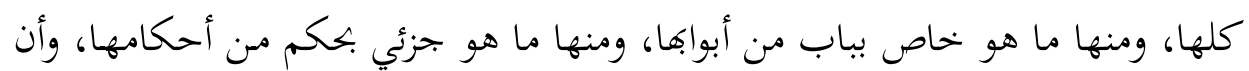

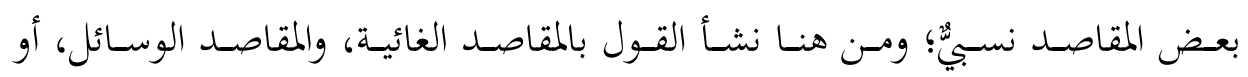
المقاصد الأصلية والتابعة.

ومَردّ ذلك إلى أن أئمة المقاصد إنما بحثوا في كل هذه المقاصد المتنوعة بما يُعيدُ نسبيّة

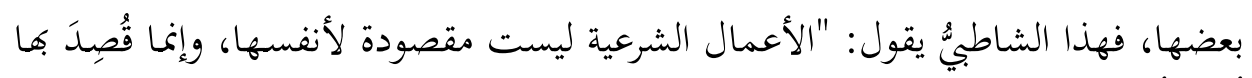

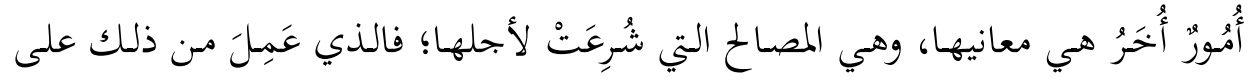

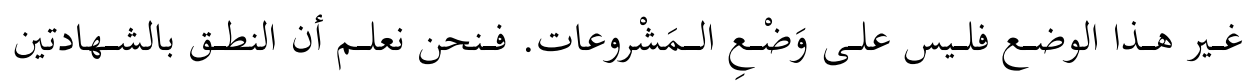

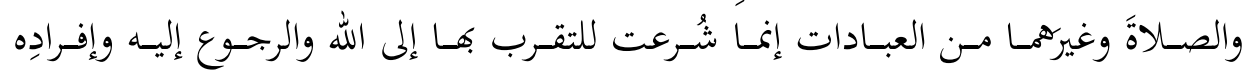

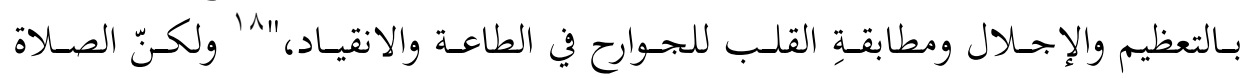

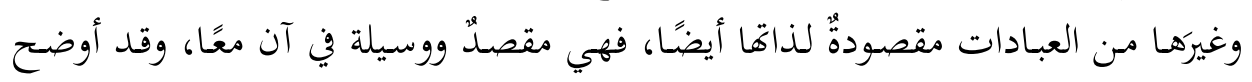

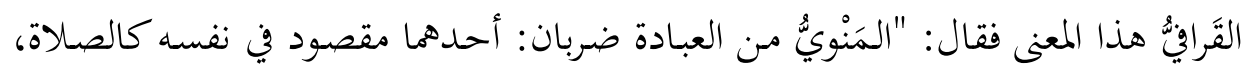

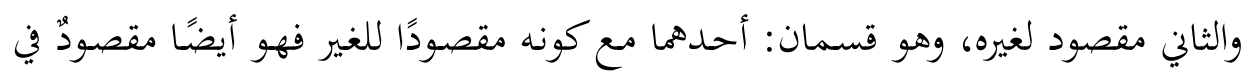

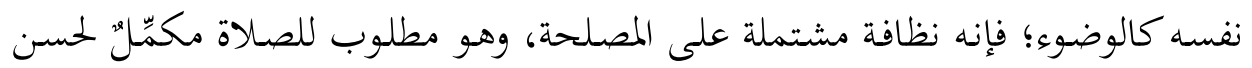

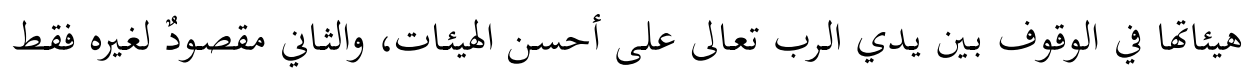

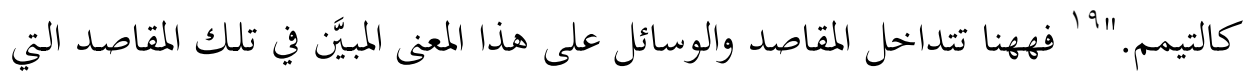
هي أيضًا وسائلُ غيرٌ متمحضة، ولذلك يجب التيقظ لدلالات الألفاظ حين قراءة كتب فئب

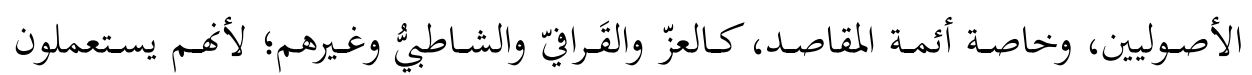
المقاصد على هذا المعنى المتعدد.

lv

- حبيب، محمد بكر إسماعيل. مقاصد الشريعة تأصيلاً وتفعيلاً، السعودية: رابطة العالم الإسلامي، سلسلة

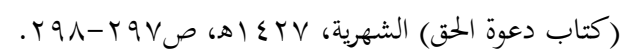

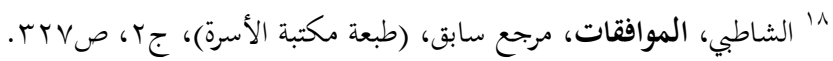

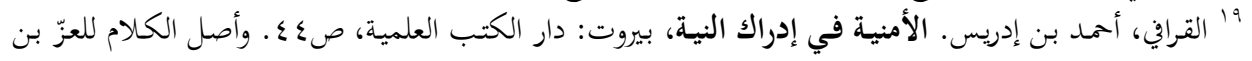
عبد السلام، في: - ابن عبد السلام، العز . قواعد الأحكام في مصالح الأنام، تحقيق: طه عبد الرؤوف سعد، القاهرة: مكتبة

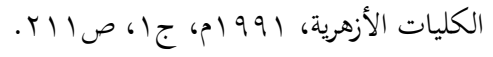


ولكنّ الأصسوليين حسين يتحـدثون عن "المقاصد والوسـائل"، يُعنَون بضبطهما على

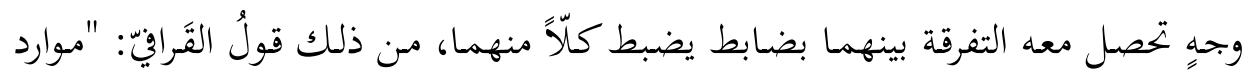

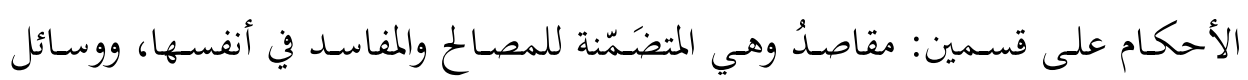

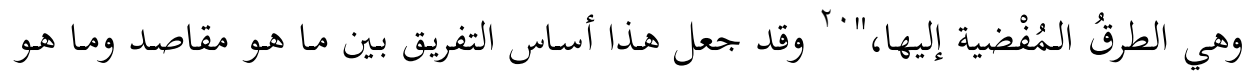

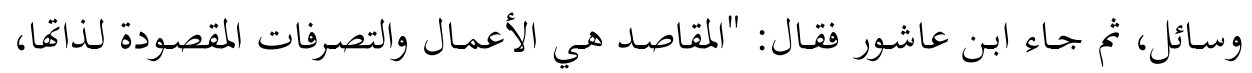

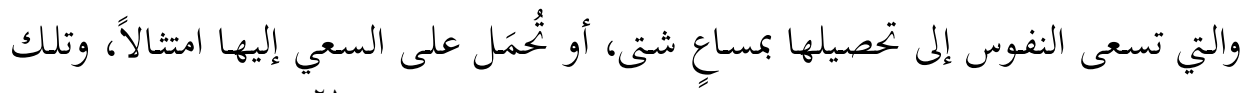

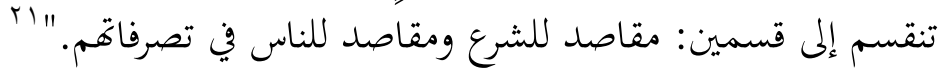

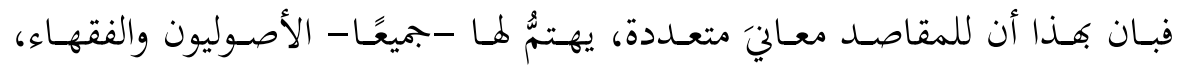

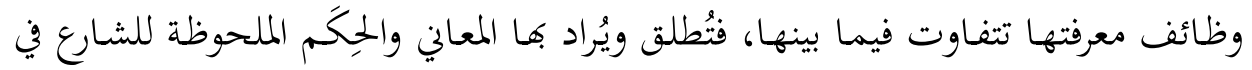

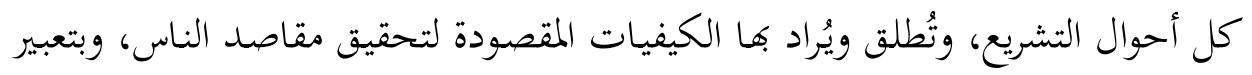

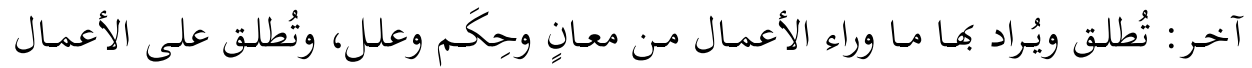

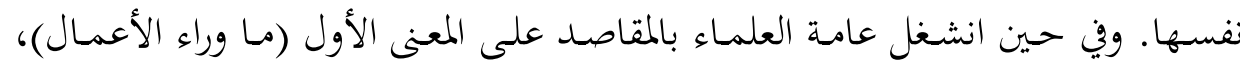

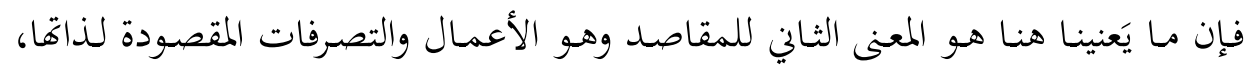
والمتضمنة للمصالح والمفاسد في ذاتيا.

أمّا الوسائلُ في اللغة فهي تَرجع إلى الجذر اللغوي (وسل)، وهي "كلمتان متباينتان

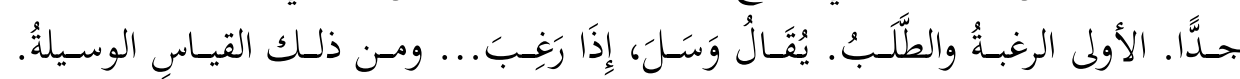

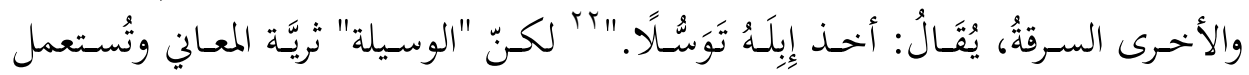

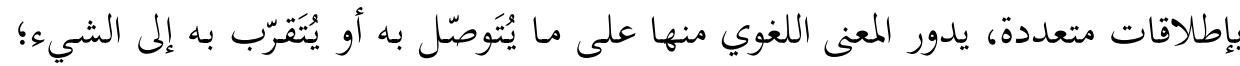

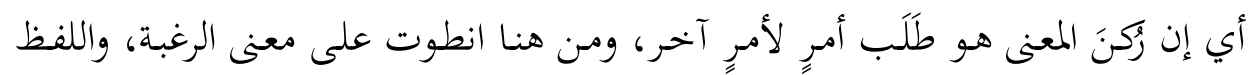

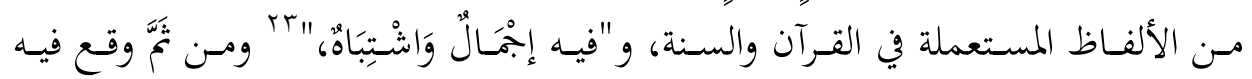
الاختلاف الشديد في مسألة التوسُّل المعروفة.

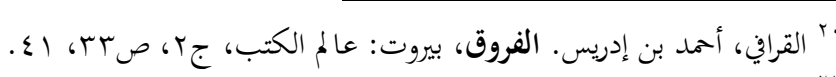

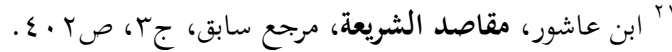

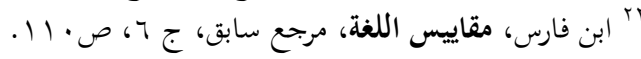

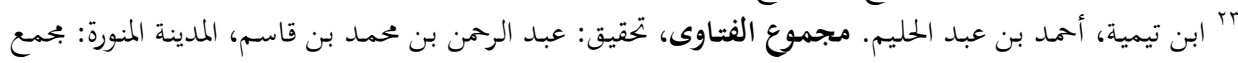

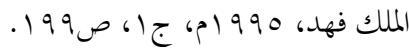




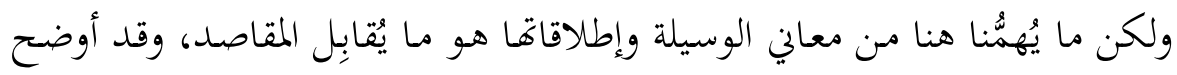

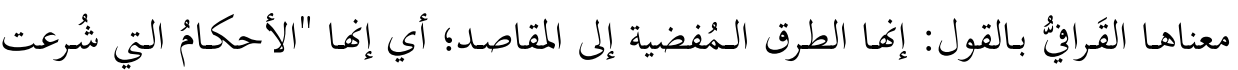

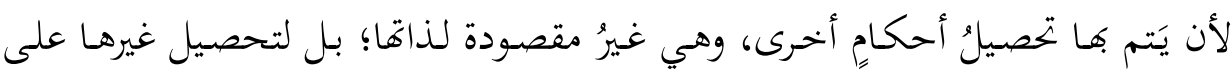

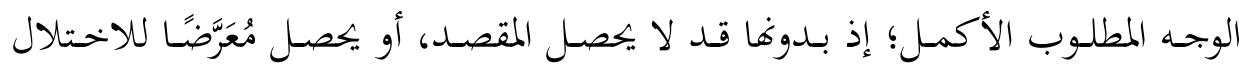

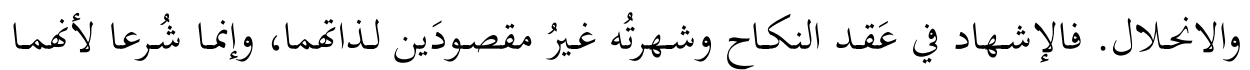

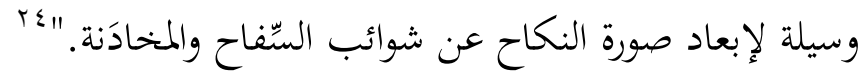

وقد اختلف الفقهاء في إطلاق لفظ الوسائل؛ فبعض الشافعية قصَروا معنى الوسيلة

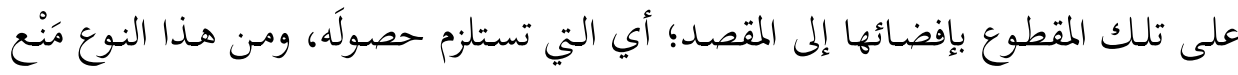

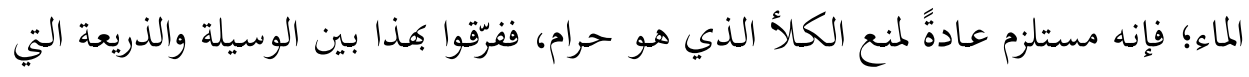

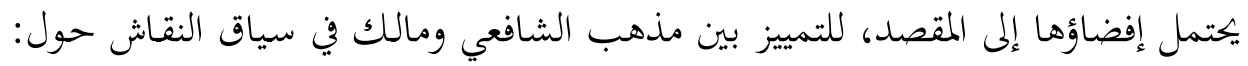

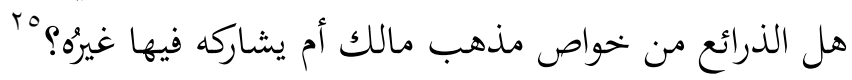

وبعضهم عرّفها بالوسائل المباحة فقط دون ما سواها من الواجبة والمندوبة والمكروهة

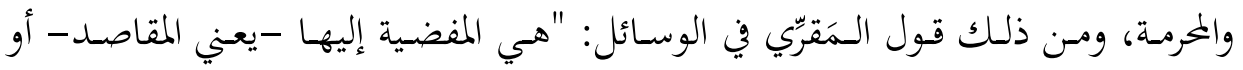

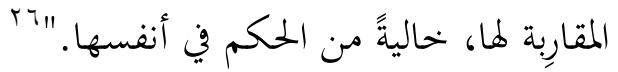

ولكنّ علماء المقاصد توسعوا في استعمالها، فقسّم العزّ بن عبد السلام الوسائلَ إلى

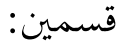

"أحدهما: وسيلةٌ إلى ما هو مقصود في نفسه، كتعريف التوحيد وصفات الإله؛ فإن إن إنان

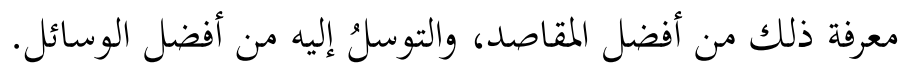

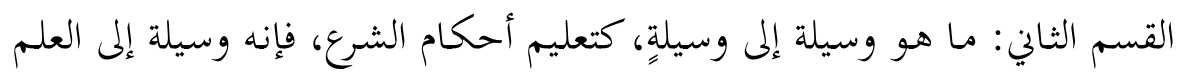

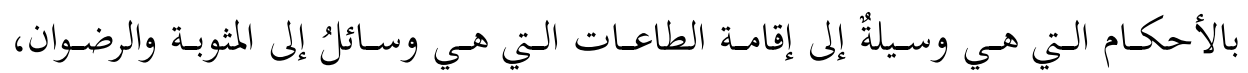

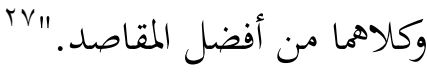

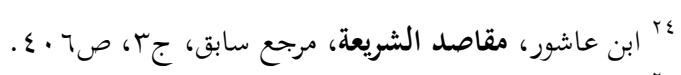

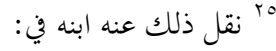

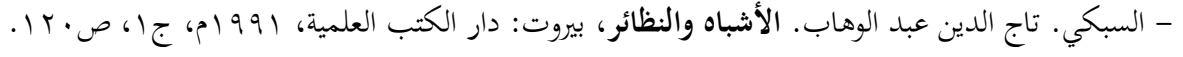

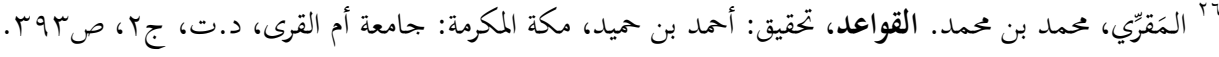


وكذلك "المعارف والعبادات: مقاصد ووسائل إلى ثواب الآخرة، والنظرُ إلى الله تعالى

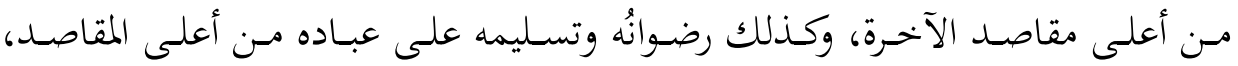

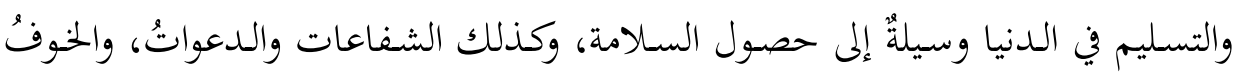

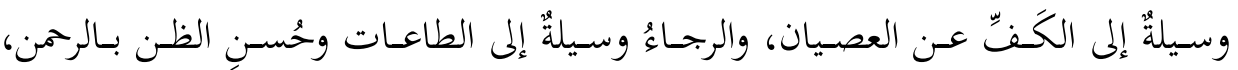

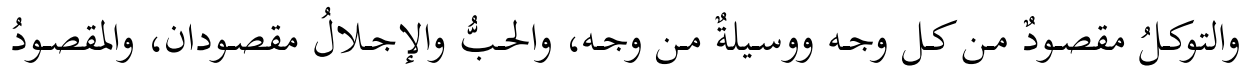

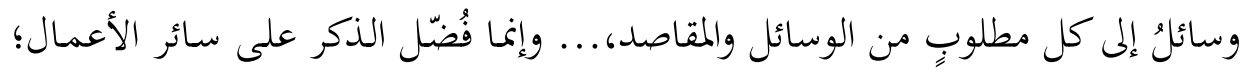

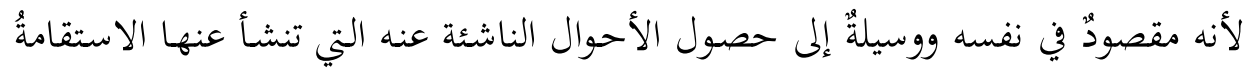

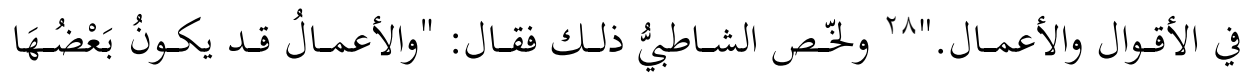

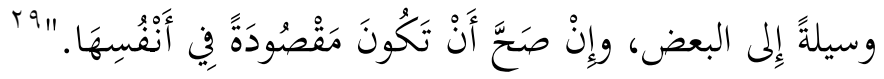

فهذا كله يؤكد ما سبق من تداخل معنى المقاصد والوسائل، وأن إطلاقات كلِّ منهما

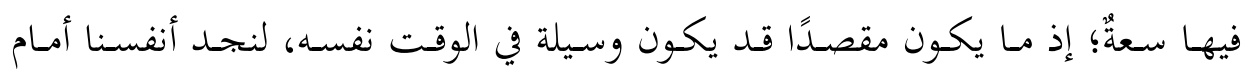

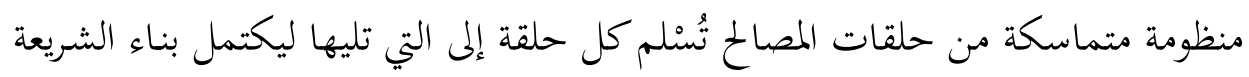
على المصالح كلها.

ومن سعة مدلول الوسائل أهما يدخل فيها الأسبابُ المعرّفات للأحكام، والشروط،

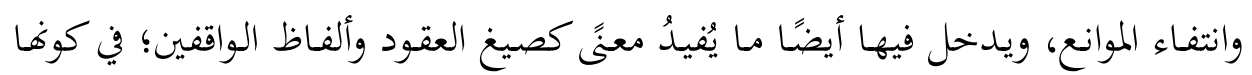

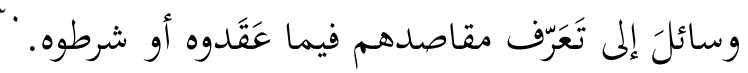

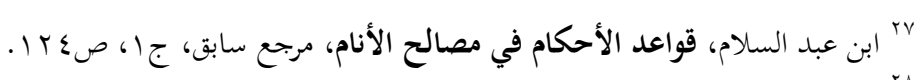

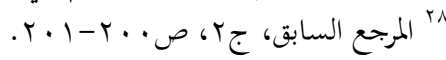

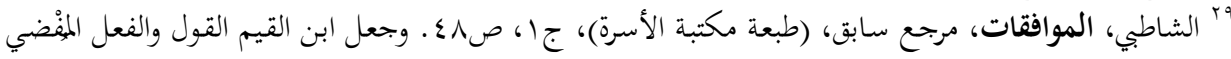

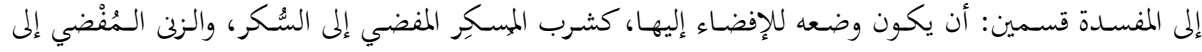

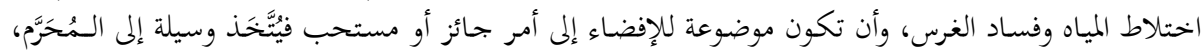

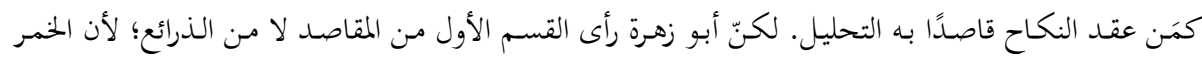

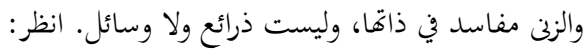

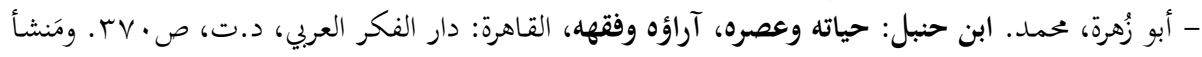

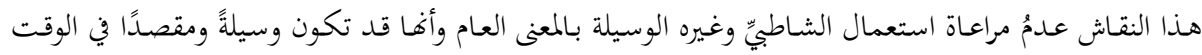

$$
\begin{aligned}
& \text { نفسه. }
\end{aligned}
$$

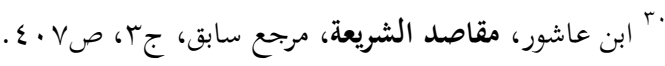


وبسببٍ مـن هذا التعدد في مدلول الوسائل واستعمالها في لغة الفقهاء والأصوليين،

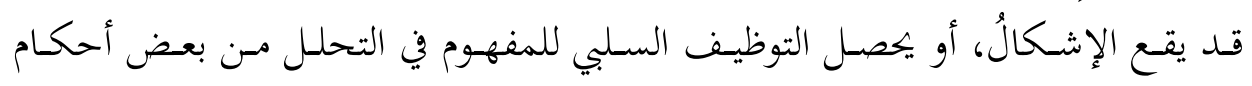

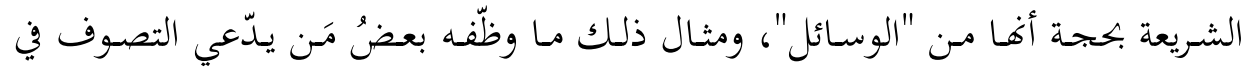

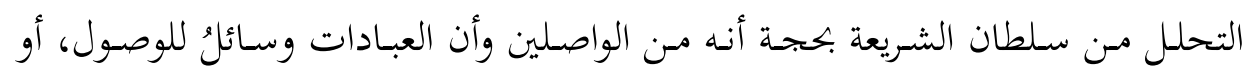

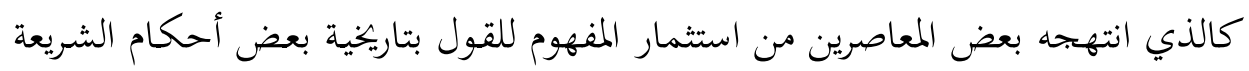
الثابتة من مدخل القول بالمقاصد.

ومنشـأ الغلط عـدمُ تحريـر المفهوم أولاً، ثم عـدم تحريـر محل الحكـم الفقهي ثانيًا مــا تحدث عنه علماء المقاصد، وأمثلتُه منثورة في كتب الفقه من دون تنظير واضح. فمن جهة المفهوم، يمكن تحريره بالقول:

إن البُعد المنظومي لأحكام الشريعة الذي انشغل بتوضيحه علماء المقاصد الأوائل،

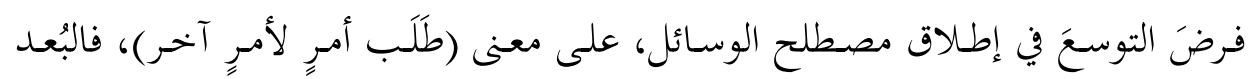

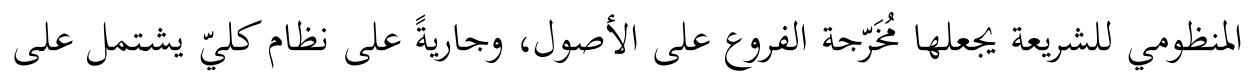

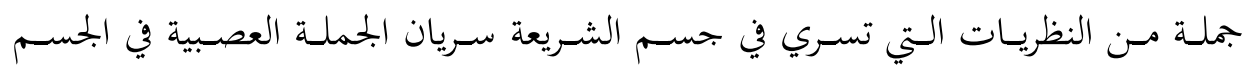
الإنساني، يُسنمم بعضُها إلى بعض لتتحقق المصالح التي هي بمنزلة الروح للجسم، ومن ثم

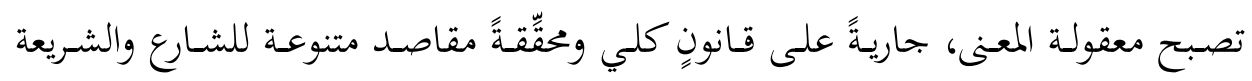

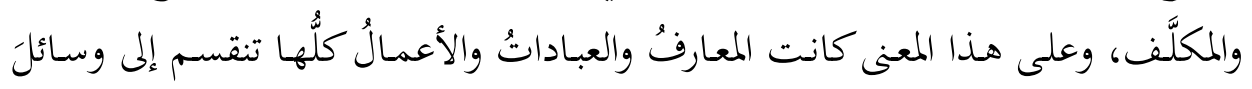

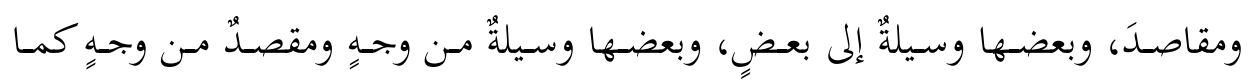

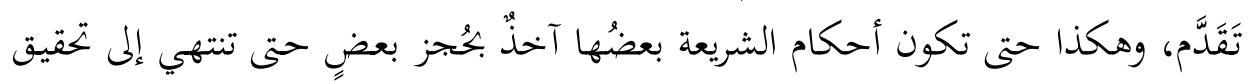
مصالح الدارين. وهـذا المعـنى الـذي نشـرحه لا تُبـنى عليـه أحكـامٌ عمليـةٌ؛ أي فقهيـة، بـل إدراكيـة؛

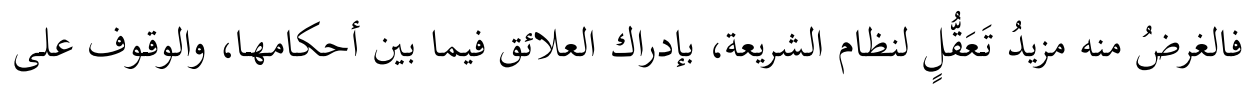

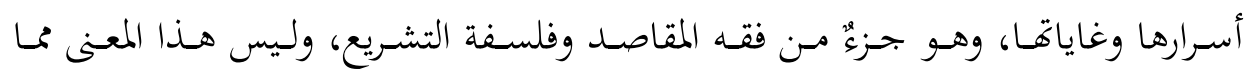
نتشاغل به هنا في هذا البحث. 


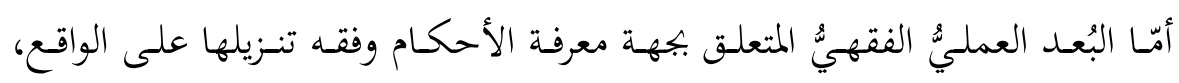
فاقتضى معنَّ خاصَّا للوسائل يظهر فيه المعنى الأداتيّ لها بوصفها وسائلَ أو طرقًا مؤديةً

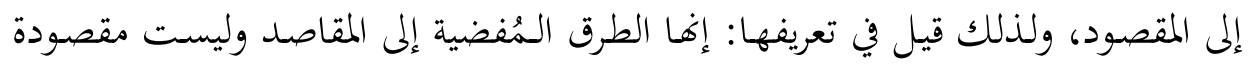

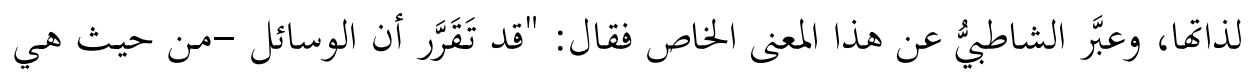

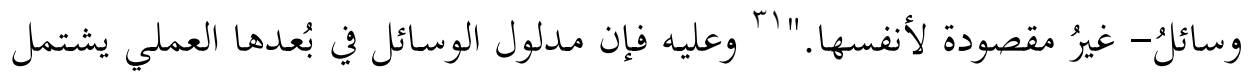

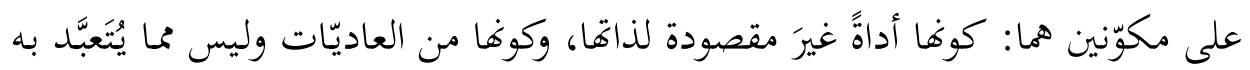

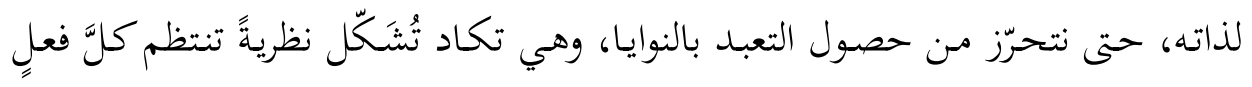

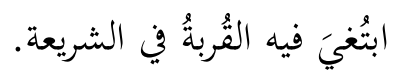

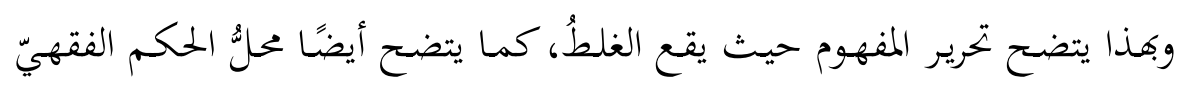

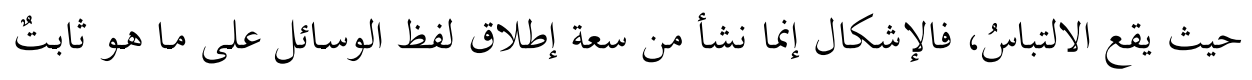

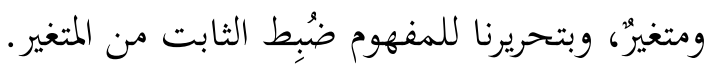

\section{ثانيًا: تاريخ المنهجية في العقل الفقهي}

يَصعبُ الحزَم بتاريخ دقيق لظهور فكرة الوسائل؛ إلا على جهة الإحالة إلى أول مَن

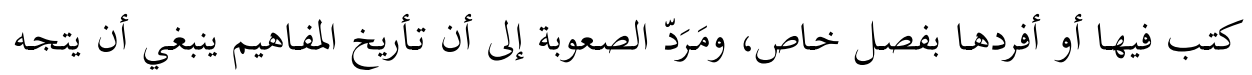

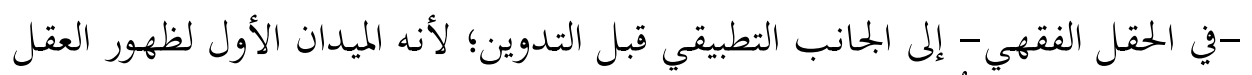

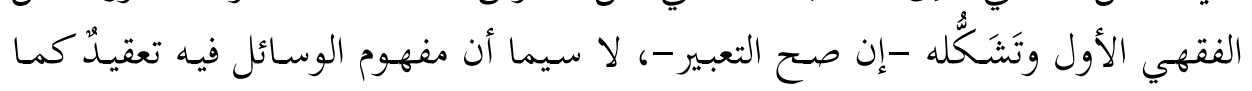
سبق، ومنشأ التعقيد فيه يرجع إلى ثلاثة أوجحه: الأول: تعدد استعمالاته ودلالاته.

$$
\text { الثاني: صلته بمفاهيم أصولية وكلامية أخرى. }
$$

الثالث: إحالته إلى الجانب التطبيقي، وهذا مما لا يختص بالنظر الفقهي فقط؛ فالمنزع

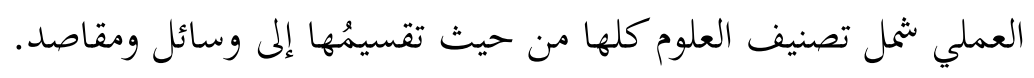

يتصل مفهوم الوسائل بمجموعة مفاهيم، منها:

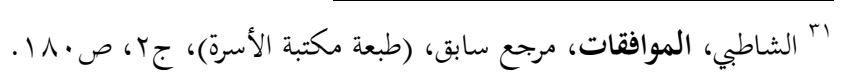




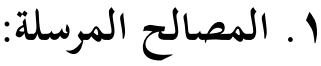

فنحن نعرف -مثلاًَ- أن ثمة وقائع متعددة نزلت في الصحابة -رضوان الله تعالى

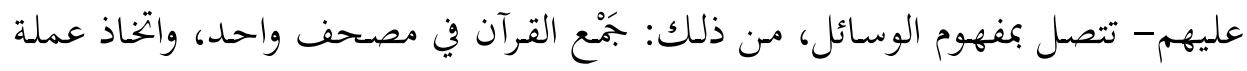

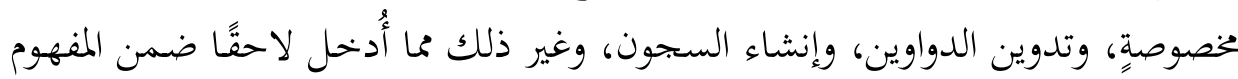

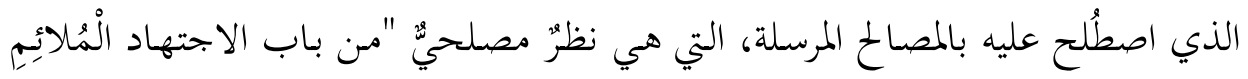

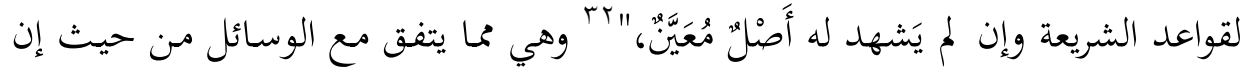

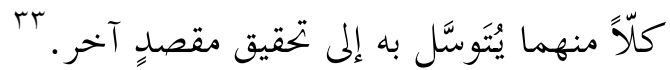

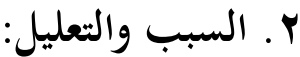

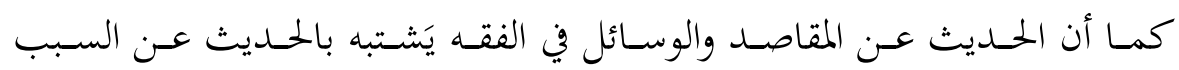

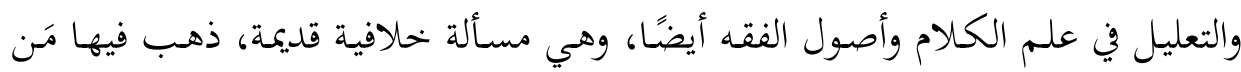

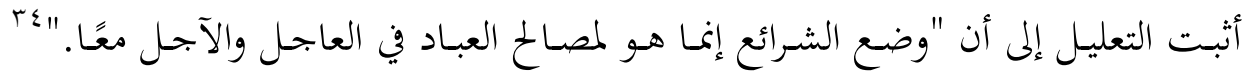

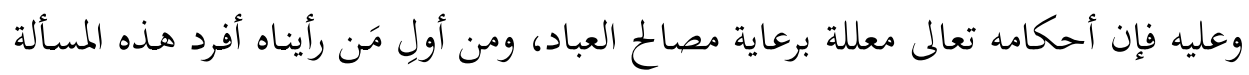

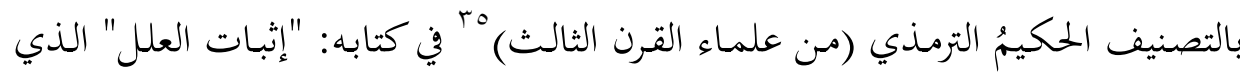

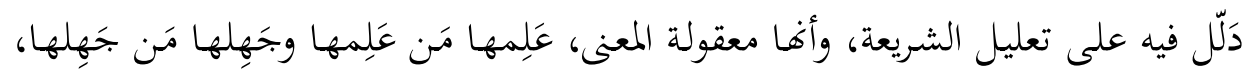

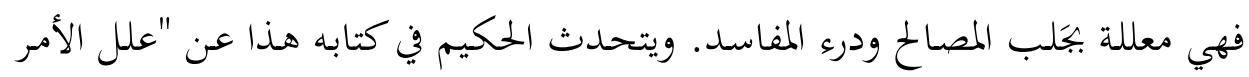

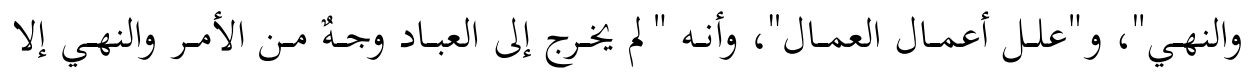

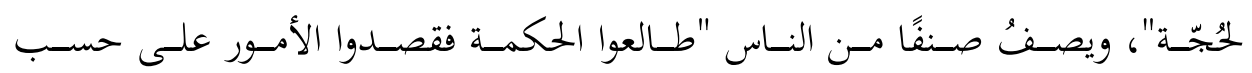

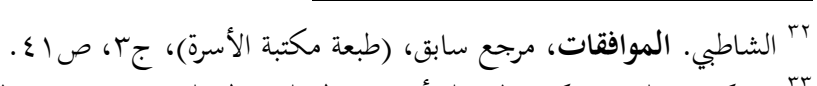

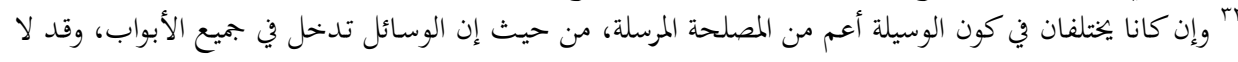

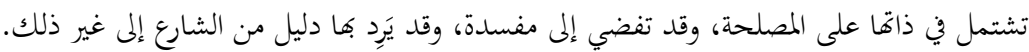

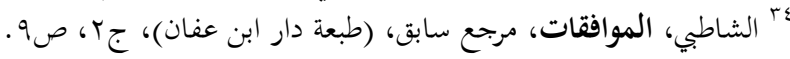

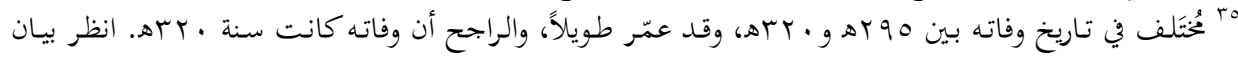
زلك في: - عبد الله، وجيه أممد. الحكيم الثرمذي واتجاهاته الذوقيـة، الإسكندرية: دار المعرفة الجامعية، 919 (م) 


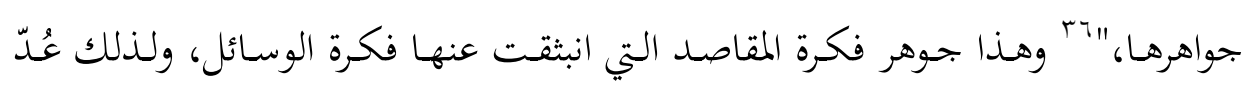

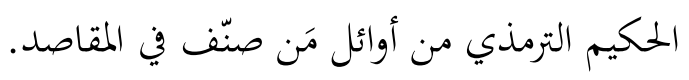

\section{r. الجانب النطبيقي للفقه:}

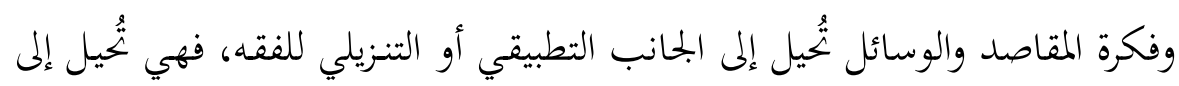

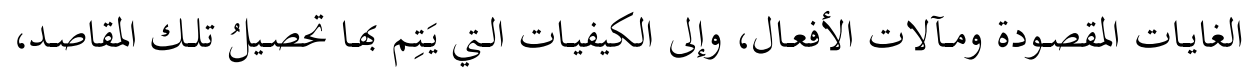

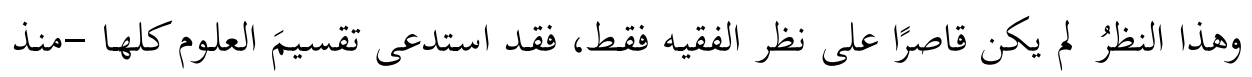

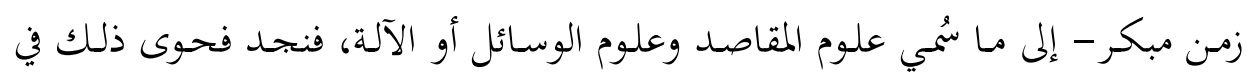

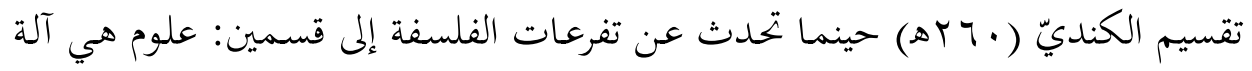

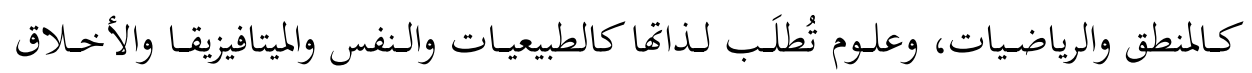

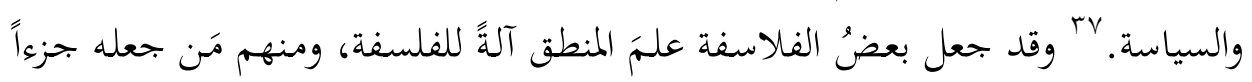

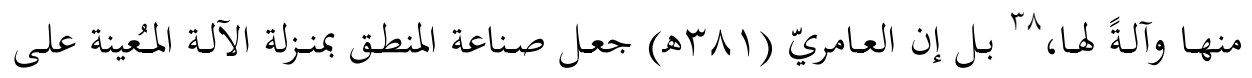

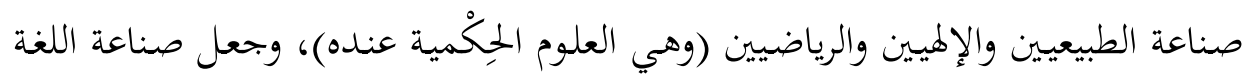

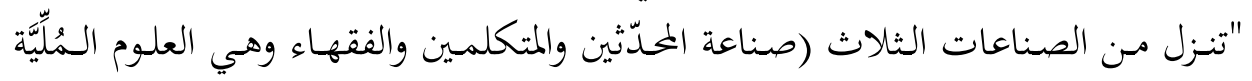

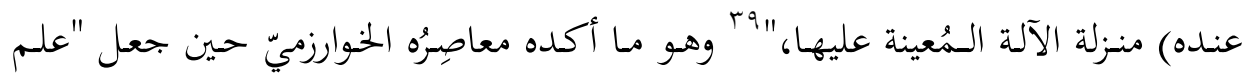

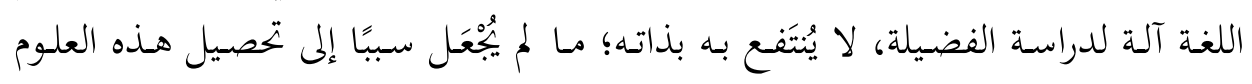
الجليلة."•؛

بr الترمذي، محمد بن علي. الحكيم إثبات العلل، تحقيق: خالد زهري، الرباط، جامعة محمد الخامس: منشورات

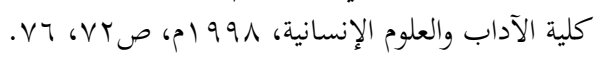

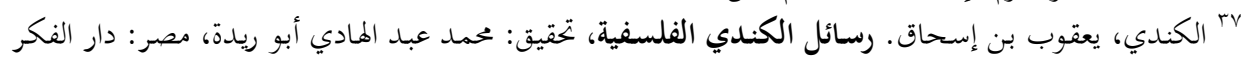

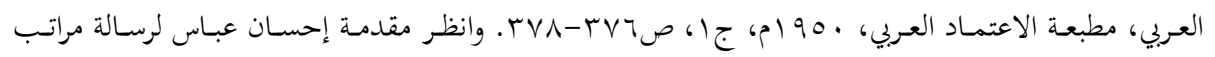

$$
\text { العلوم لابن حزم في: العربي مطبعة الاعنقاد }
$$

- ابن حزم، علي بن أحمد. رسائل ابن حزم، تحقيق: إحسان عباس، بيروت: المؤسسة العربية للدراسات والنشر،

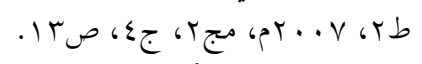

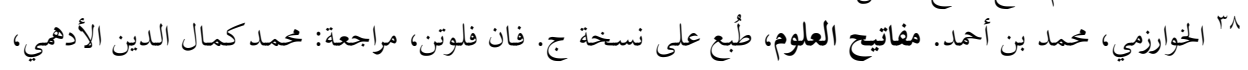

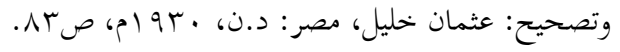

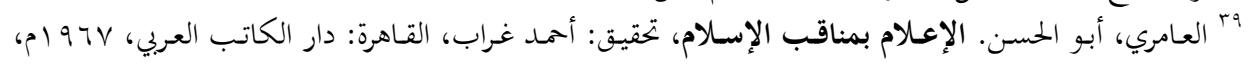
. $\wedge \varepsilon ص$ • الخوارزمي، مفاتيح العلوم، مرجع سابق، صـ. 


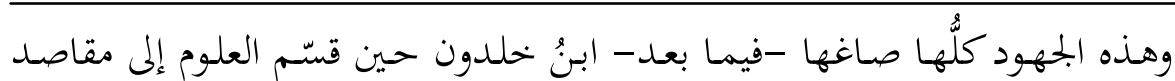

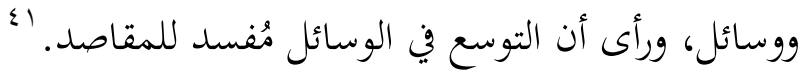

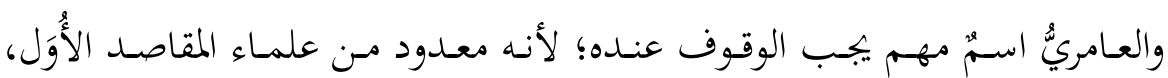

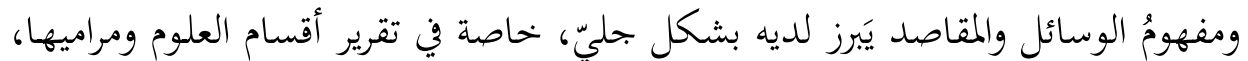

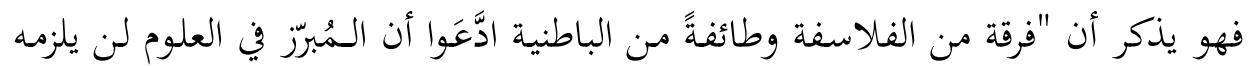

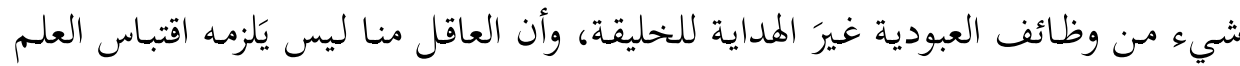

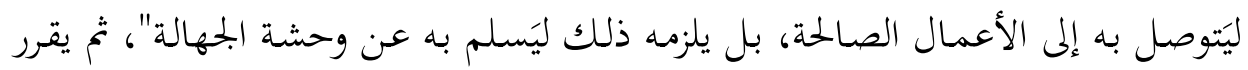

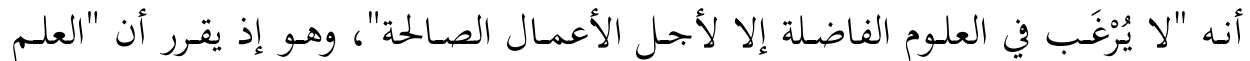

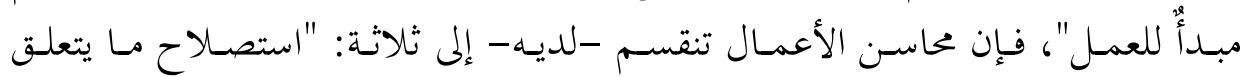

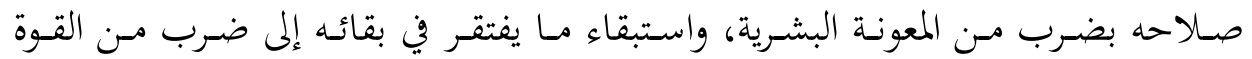

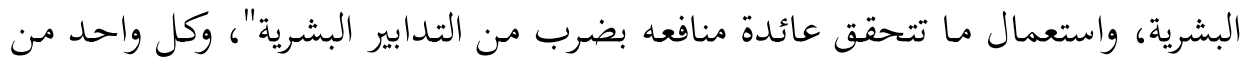

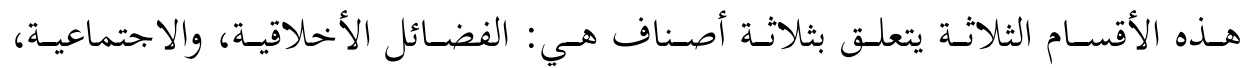

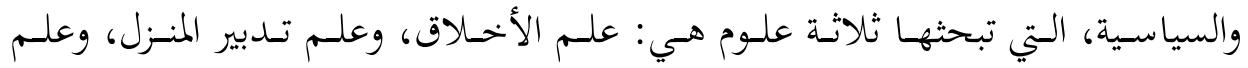

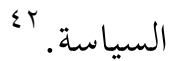

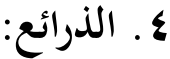

لكن، يمكن لنا أن نسجل أن البدايات الأولى للتنظير لفكرة الوسائل في الفقه ترجع

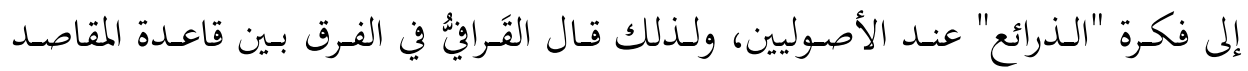

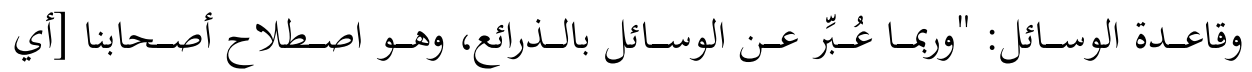

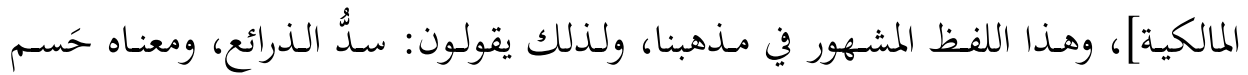

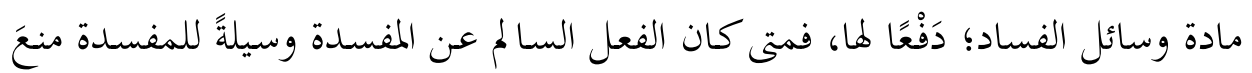

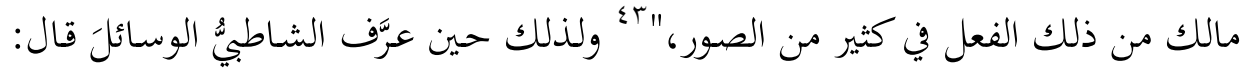

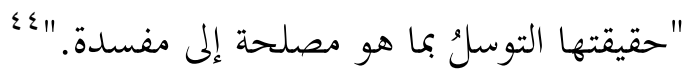

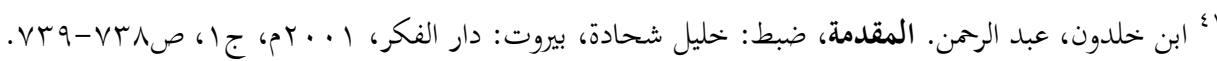

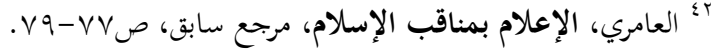

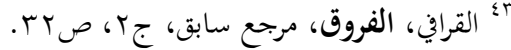

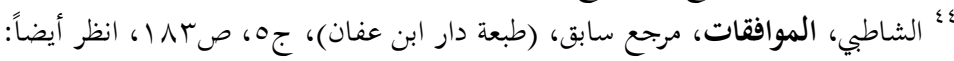




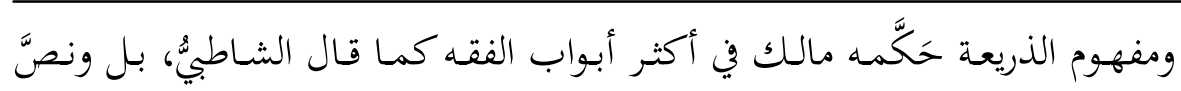
عليه مستعملاً لفظ الذريعة، من ذلك قوله في مَن اشترى طعامًا واكتاله، ثم جاءه مشترٍِ فأخبره بأنه اكتاله واشتراه لنفسه، فاشتراه المشتري الآخر على تلك الصفة مصَدَّقًا له،

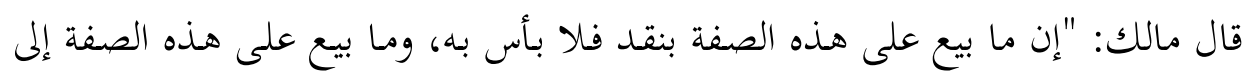

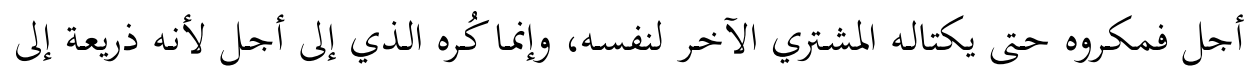

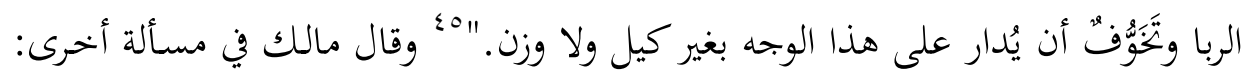

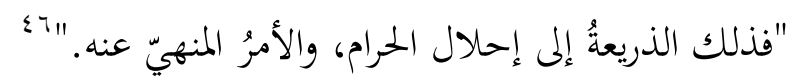

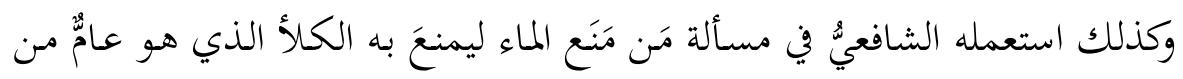

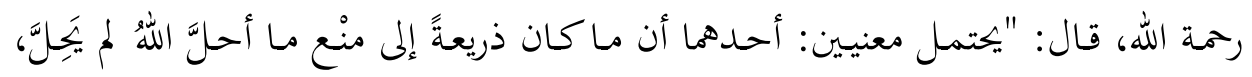

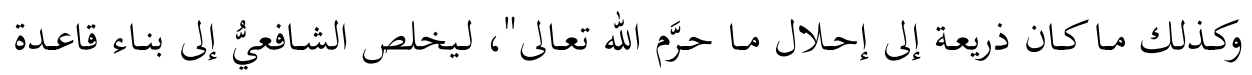

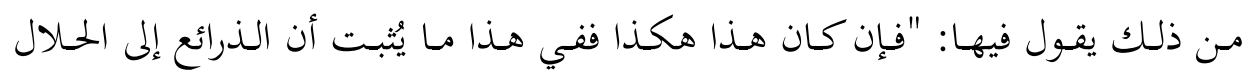

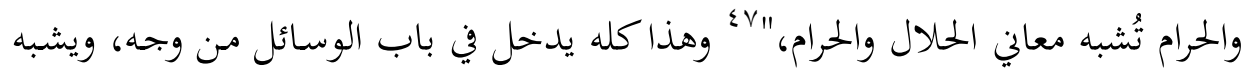

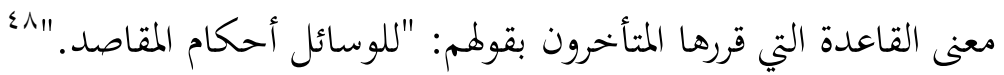

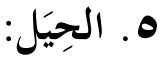

ومما يشتبه بفكرة الوسائل كذلك مفهومُ الحيل في الفقه، من حيث إن التَّحَيُّل هو

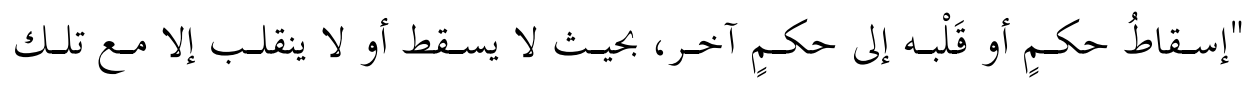

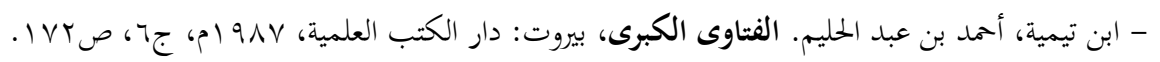

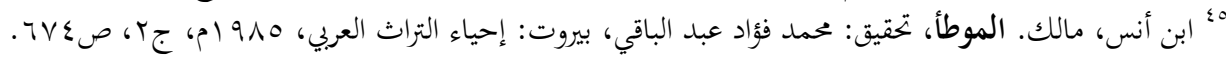

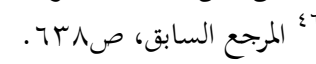

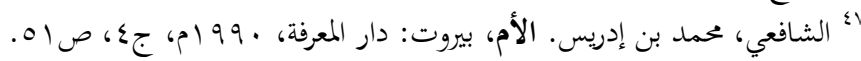

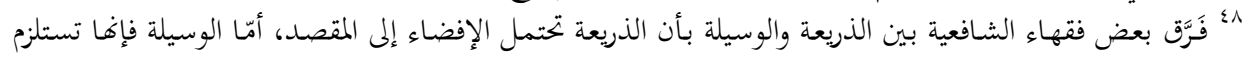

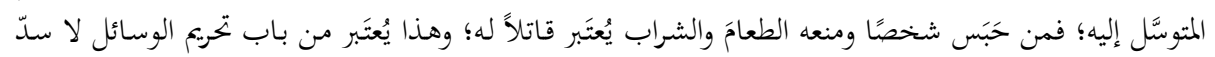

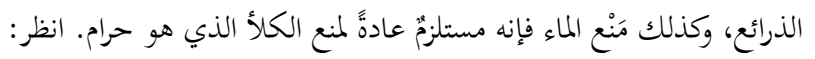

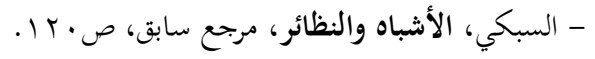

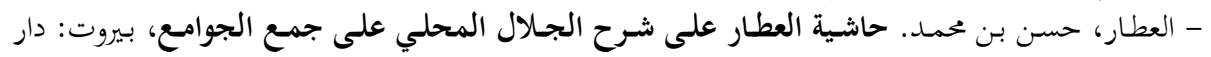

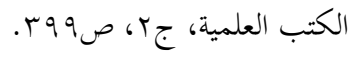




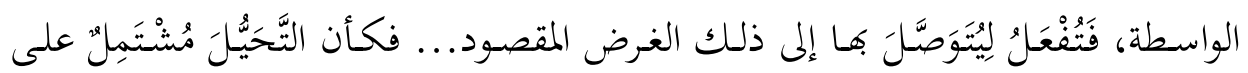

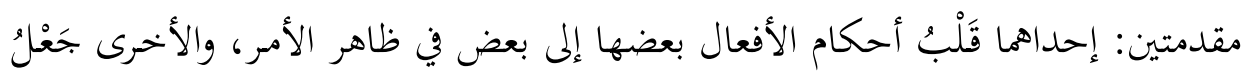

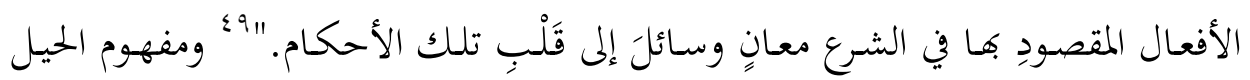

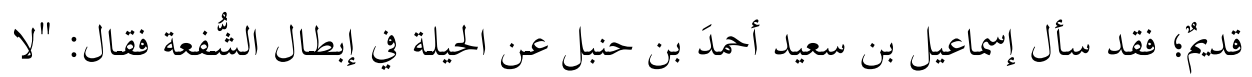

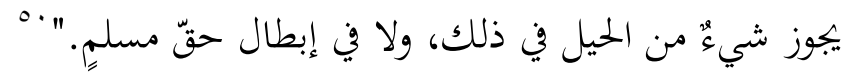

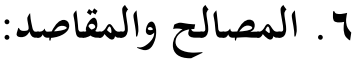

لكـنّ فكرة الوسـائل، وإن كانـت حاضـرةً في بعض القواعـد الفقهيـة مثل "مقدمـة

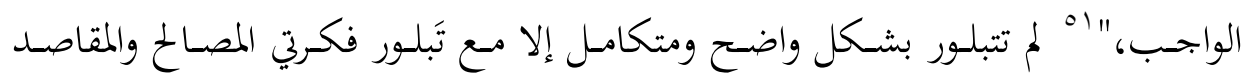

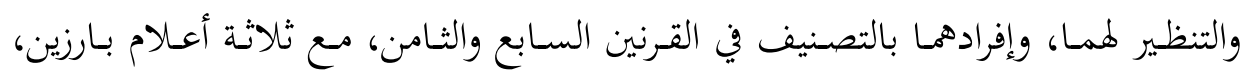

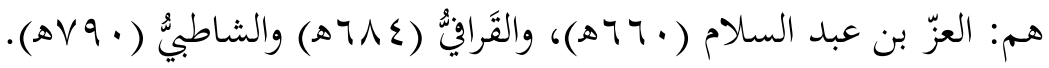
أمّا العزّ بن عبد السلام فإليه يرجع الفضل في التنظير لفكرة المصالح في كتابين:

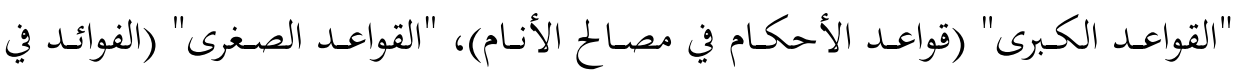

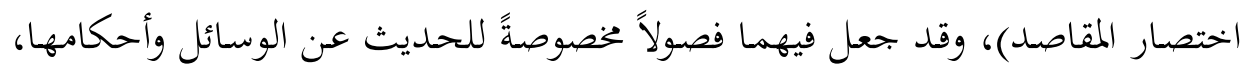

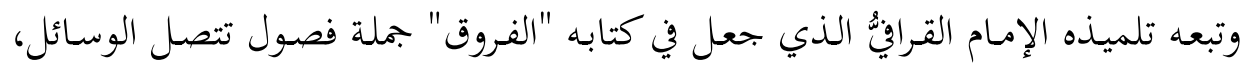

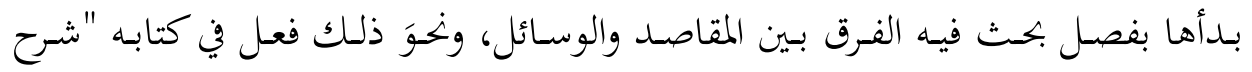

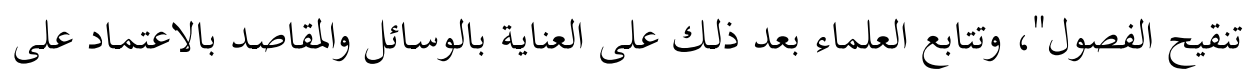

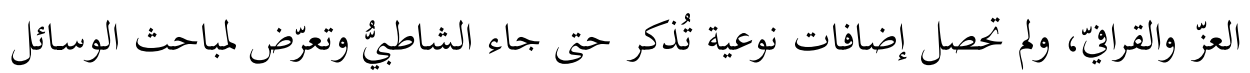

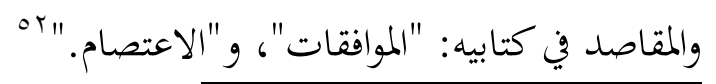

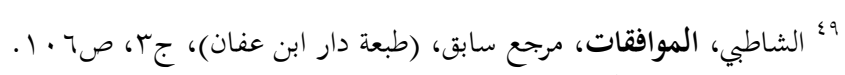

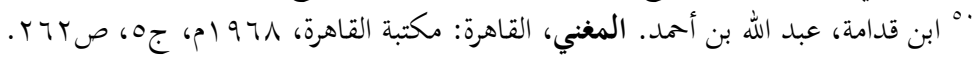

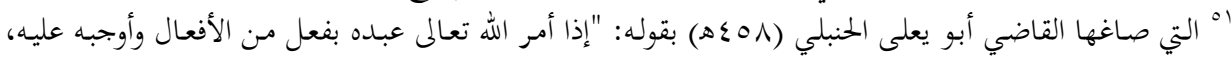

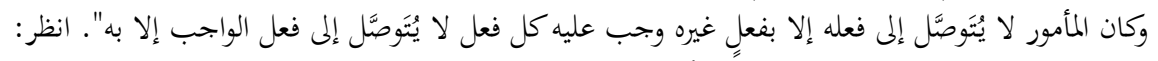

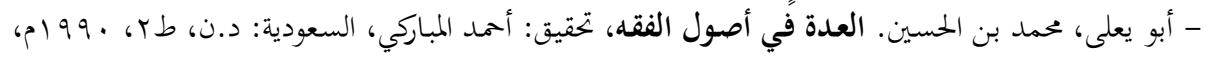

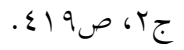
ما انظر جهود العلماء في بيان الوسائل في القرن الثامن وما بعد في:

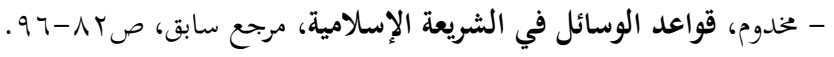


ثالثًا: منهجية المقاصد والوسائل

قد تقرر أن للمقاصد والوسائل معانيَ متعددة، وأن العلماء توسعوا في دلالات كلِّ

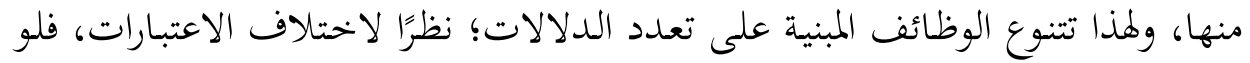

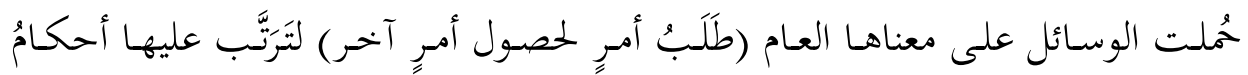

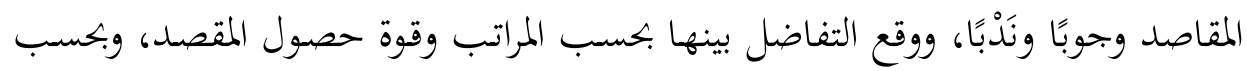

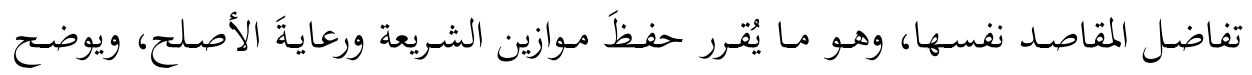

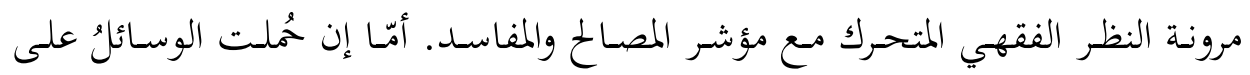

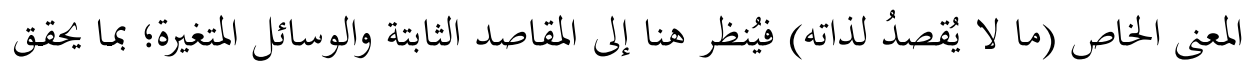

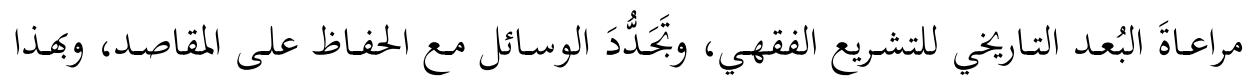
تُحَّل مشكلة الثابت والمتغير.

ولتوضيح ما يسميه البحث "منهجية المقاصد والوسائل" لا بد من معالجة مبناهـا وطريق إثباها، واختلاف الفقهاء فيها، وتقسيمها، وقواعدها على الوجه الآتي:

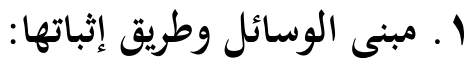

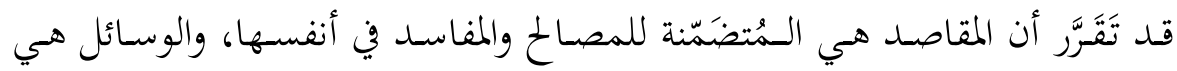

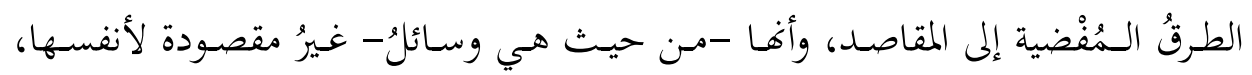

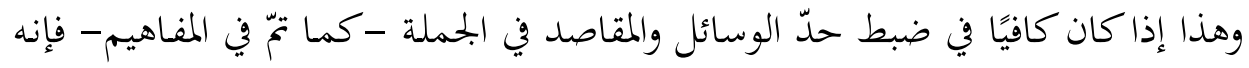

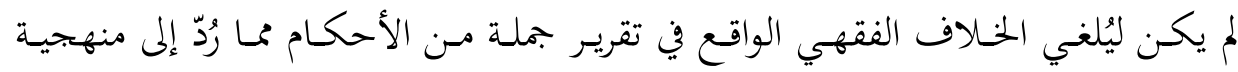

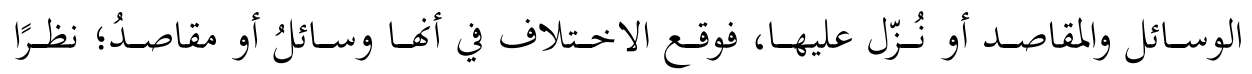

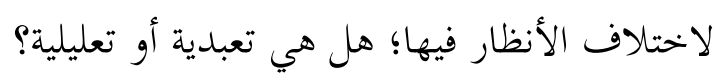

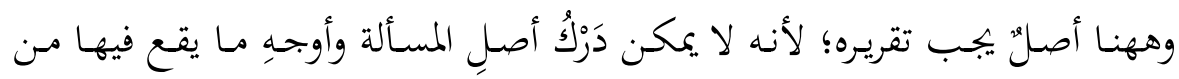

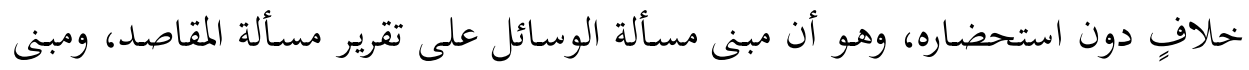

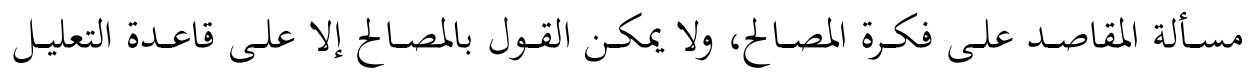

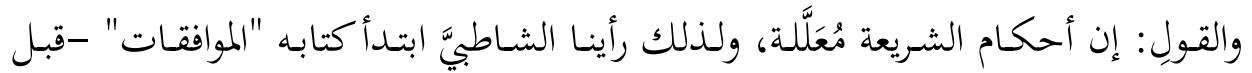




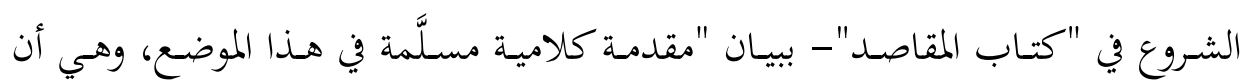

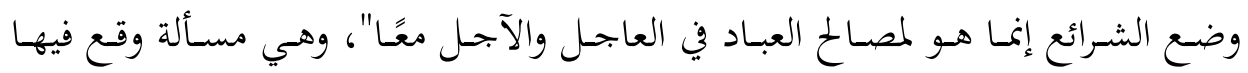

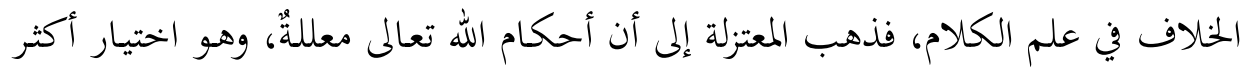

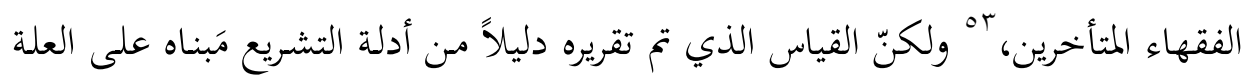

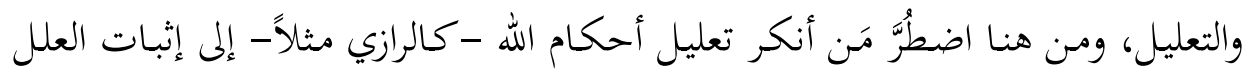

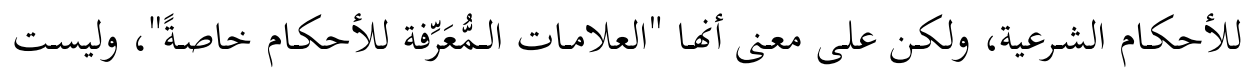

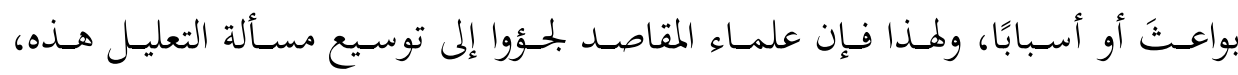

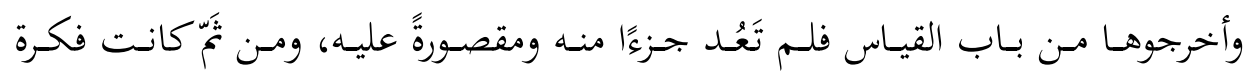

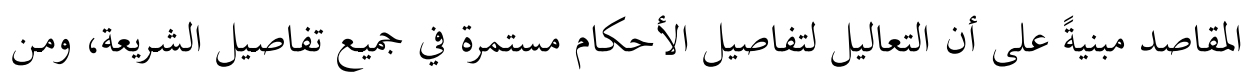

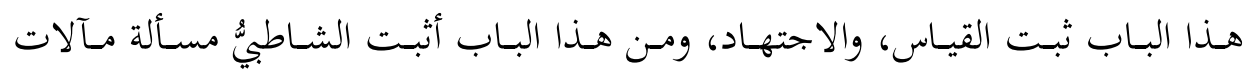

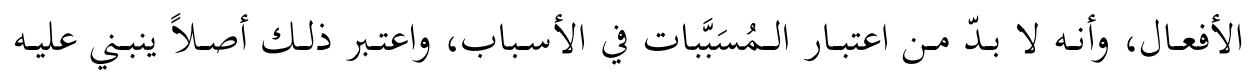

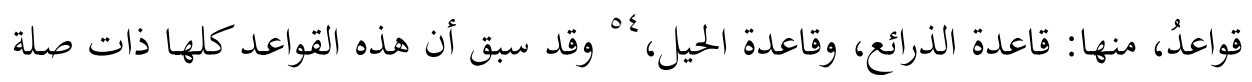

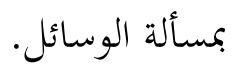

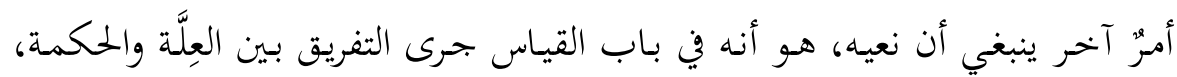

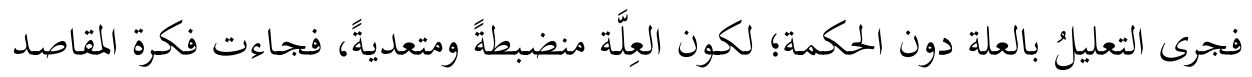

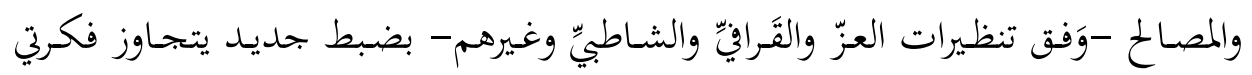

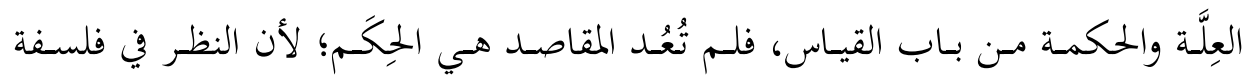

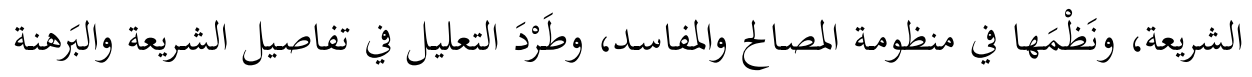

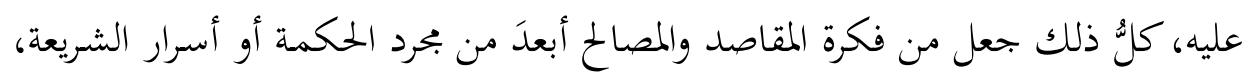

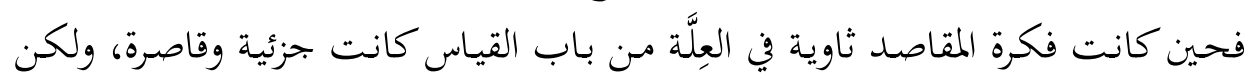

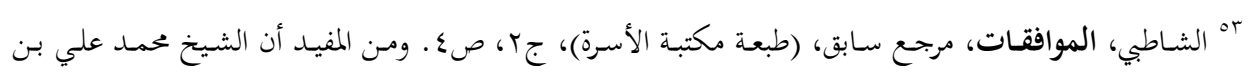

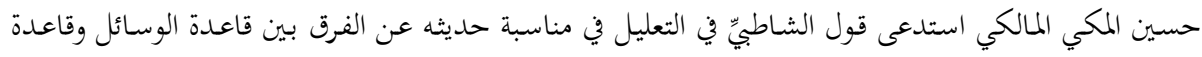

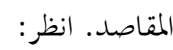
- المكي، حمد علي. تهذيب الفروق والقواعد السَّبَّة في الأسرار الفقهية، مطبوع بحاشية الفروق للقرافي، جن،

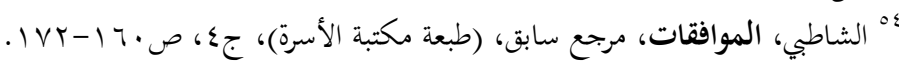




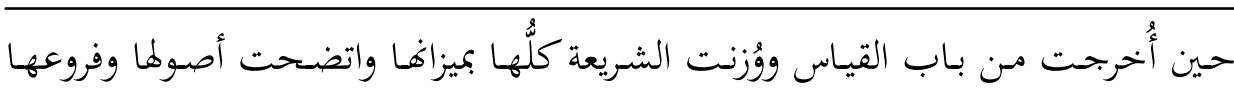

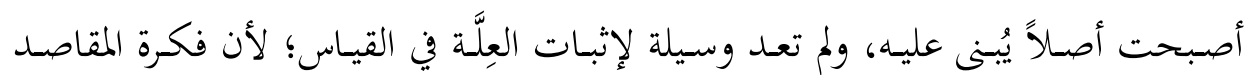

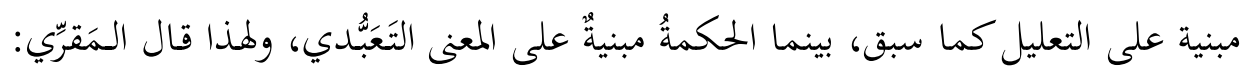

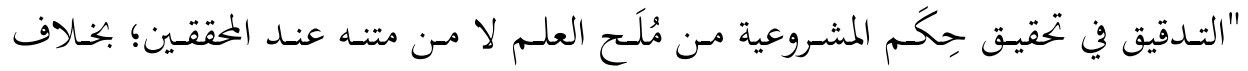

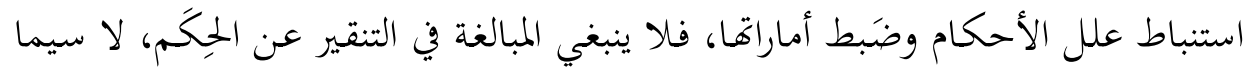

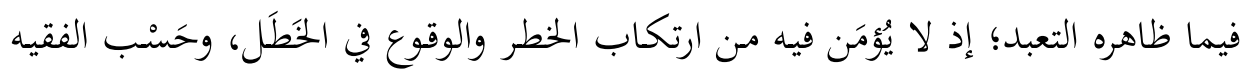

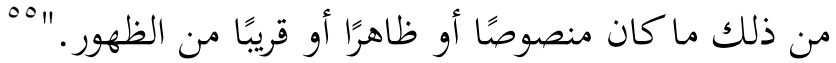

وقد وضع الشاطبيٌ أصلاً للفرق بين التعبدي والتعليلي، وعبّر عن التعليلي في بعض

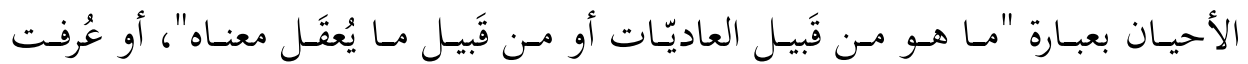

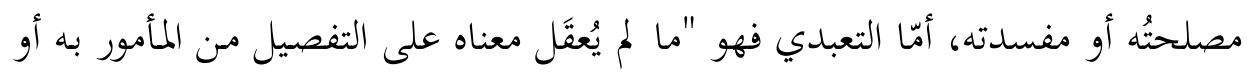
المنهي عنه."

ومع كون الشاطبيّ أصَّل قانونًا عامَّا: أن الأصل في العبادات التعبُّد وفي المعاملات التعليل، فإنه أوضحَ مسألة مهمة -بناء على الضابط السابق للعادي والتعبدي- يتداخل

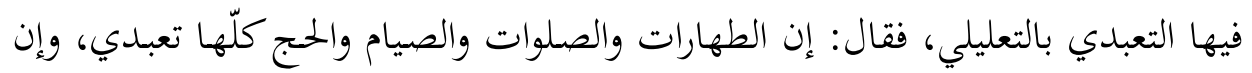
البيع والنكاح والشراء والطلاق والإجارات والجنايات كلها عادي؛ لأن أحكامها معقولة

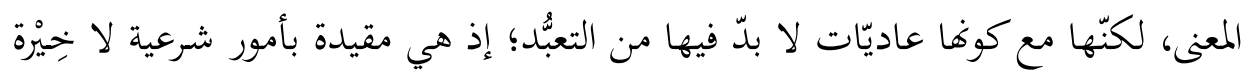
للمكلف فيها، وبهذا بان الاشتراك في القسمين في معنى التعبد، ولذلك رتّب عليه مسألة دخول الابتداع من هذا الوجه في العاديّات كالعباديات.

وغرضي هنـا بيـان ضـابط العـادي والتعبـدي؛ لأنتي أرى أنه يَصـلح اعتبـاره هنـا في

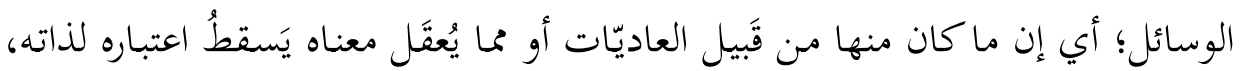

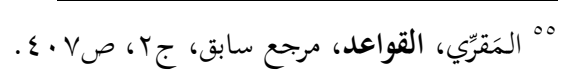

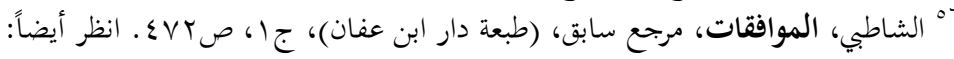

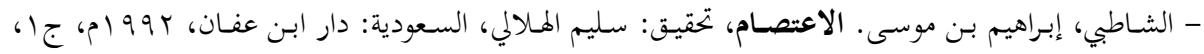


ويُنظرَ فيه إلى ما يجقق المقصد؛ لا سيما إذا لمُ يأت النصٌٌ أو الدليل على أنه مُقَيَّدُ بـأمر شرعي لا خيرة للمكلف فيه، أو كان مما يخضع للتغير أو التجدد.

\section{ץ. اختلاوف الفقهاء في الوسائل:}

وإذا كنا قد قررنا حقيقة الوسائل وأساس إثباها على هذا النحو، فمن المفيد الإقرار

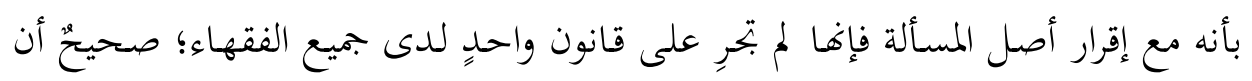

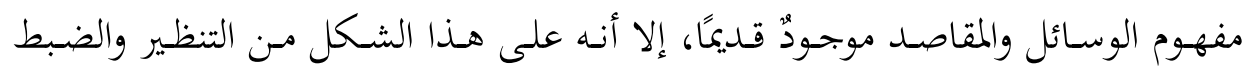

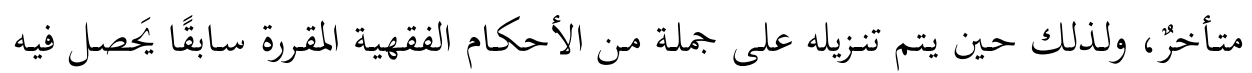
الخُلْفُ، بـل إن الخـلاف بين الفقهاء يقع -قبـل ذلك- في تقرير المقاصد والوسائل تبعًا للخحاف في أصله وهو التعليل. والخلاف الفقهي يقع هنا من أوجه:

أولها: هـل تلك الوسيلة مـن بـاب العبادات أو العـادات؟ كمـا في زكاة الفطر؛ هـل

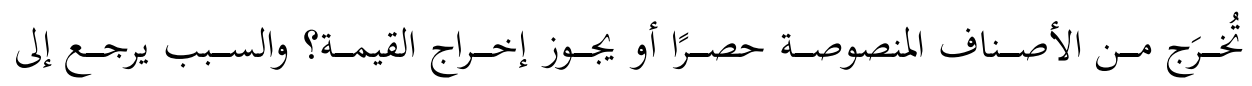

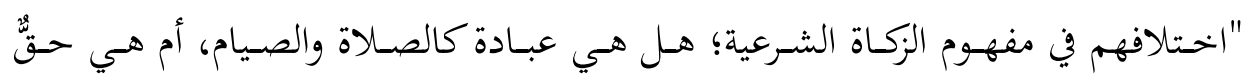

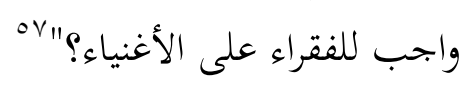

وثانيها: أن الخلاف قد يقع من جهة الاختلاف في تعيين المقصد، ففي زكاة الفطر

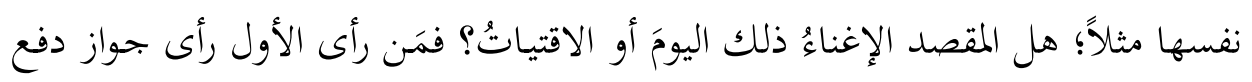
القيمة، ومَن رأى الثاني حصر الإخراج في القوت.

وتالثهـا: أن الخـلاف قــ يقـع في تعيـين الشـيء؛ أهـو وسـيلة أم مقصـد؟ كمــا في الاعتكاف مثلاً، فمَن رآه مقصدًا رأى أن الحلوة في ذاتحا مقصودة، ومَن رآه وسيلة قال: إن الاعتكاف ليس مقصودًا لذاته بل مقصودٌ منه حصول التعبد لله، قال المَقرِّي: "قال النعمان [بن ثابت أبو حنيفة]: ليس الاعتكاف في نفسه بعبادة مقصودة، وإنما يصير

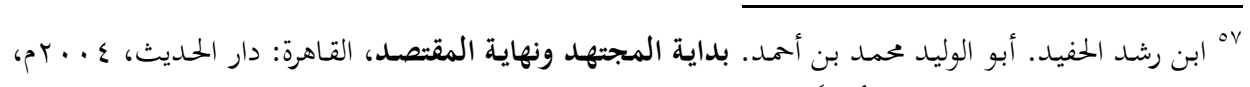

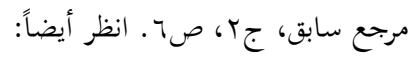

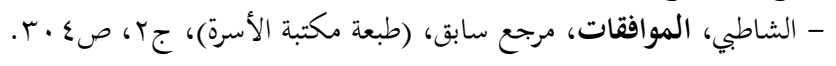


عبادةً بالصوم،... وقال الشافعي: أصل شرعية الاعتكاف طلَبُ ليلة القدر، فلا يليق به

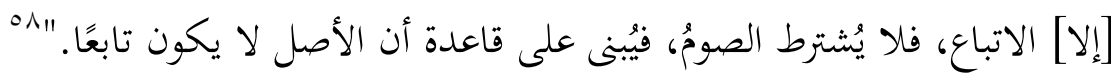

ولا ينبغي أن تساق مثل هذه الاعتبارات لتأبيد الخلاف أو للتخيير بين الآراء؛ وإلا

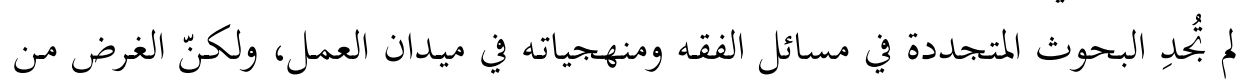

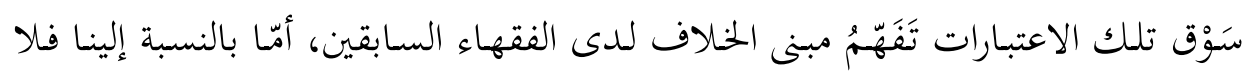

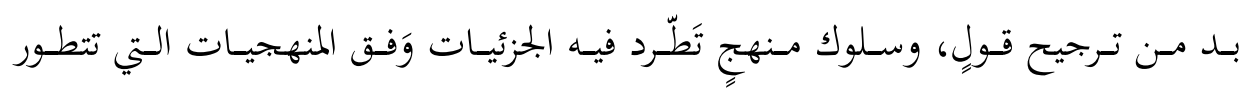
باستمرار، فيُضيف فيها اللاحق إلى السابق.

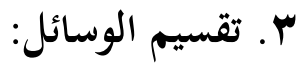

جرت تقسيمات عديدة للذرائع التي قلنا: إفـا الوسائلج في لغة المالكية قبل نضوج

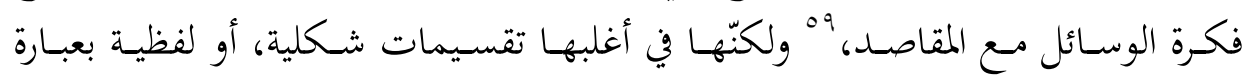

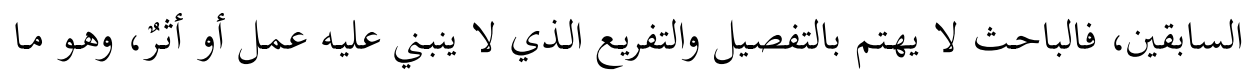

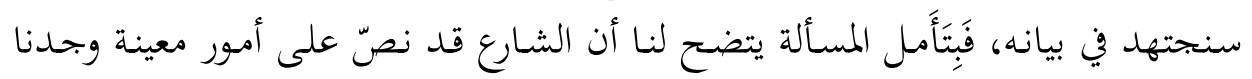

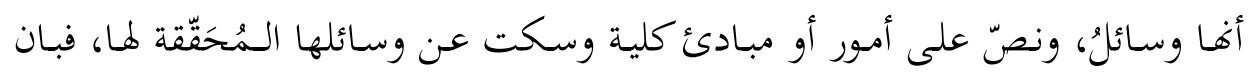

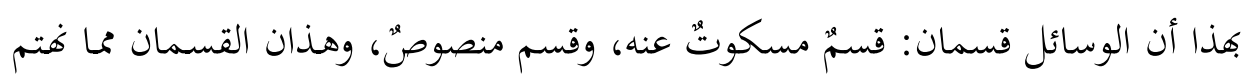

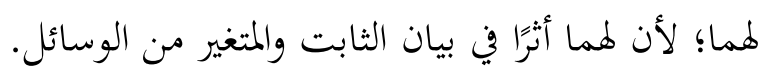

أمّا القسم المسكوت عنه فقد بَنيته على قاعدةٍ ذكرها الشاطبيُّ في قوله: "كلهُ دليل

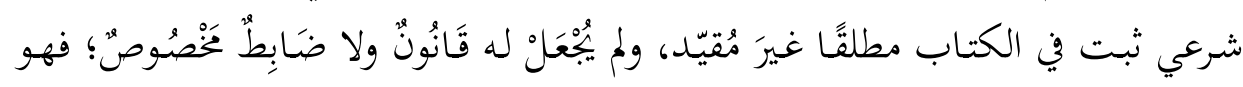

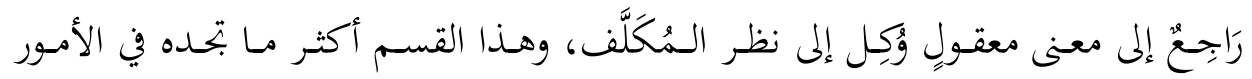

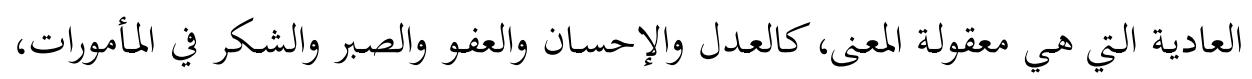

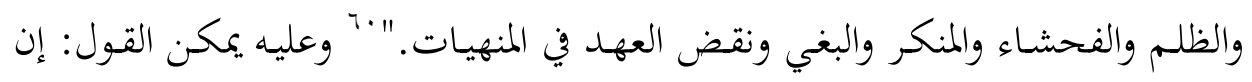

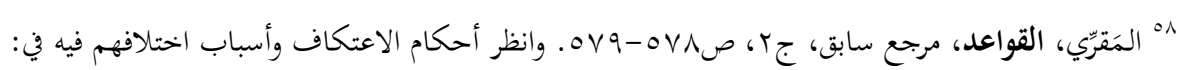

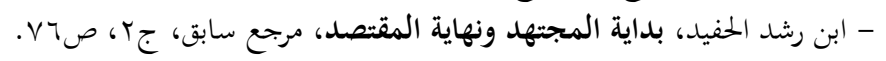

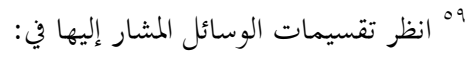

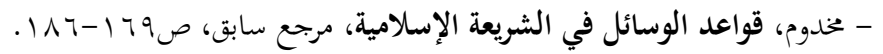

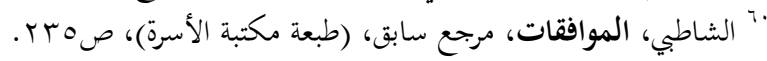


العدل والإحسان والعفو مقاصدُ متضمنةٌ للمصلحة في ذاقا، سكت الشارع عن وسائلها

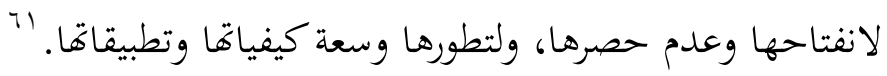

وأمّا القسم المنصوص عليه فإنه مما يقع فيه الاختلافُ، وهو محل الاجتهاد والتحرير؛ لحرص فئة من المجتهدين على الامتثال للنصوص عامة، ولوقوف الظاهرية على الظواهر وإنكار المقاصد، ولذذا عُدّ إغفال منهجية التمييز بين المقصد الثابت والوسيلة المتغيرة في

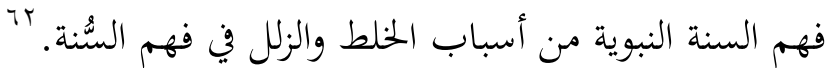

\section{ع. المقاصد الثابتة والوسائل المتغيرة:}

من طبيعة المقاصد أها ثابتة؛ ما دامت مطلوبة لذاتها، ومن طبيعة الوسائل أها من حيث هي وسائل غير مطلوبة لذاتا؛ أي إهـا غير ثابتة، ولكن ثمة قاعدة قرهـا العلماء

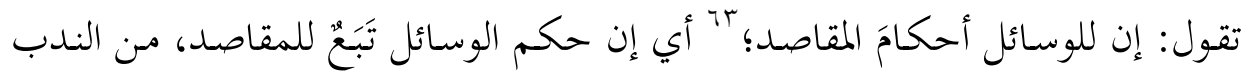

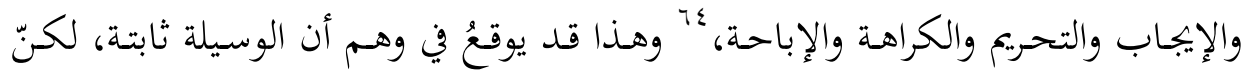

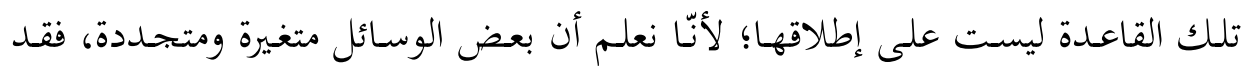

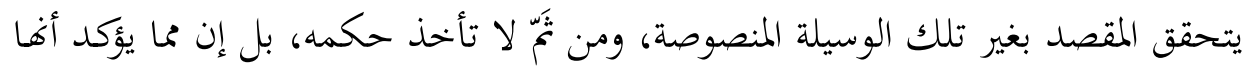

البَحَدر الإشارة هنا إلى أن الشيخ يوسف القرضاوي ذكر مسألة "تقرير المقصد الشرعي دون تعيين وسيلة" في كتابه:

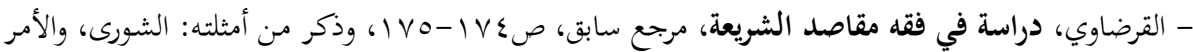

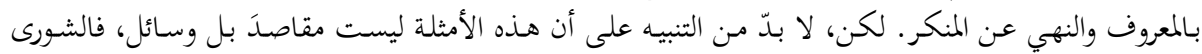

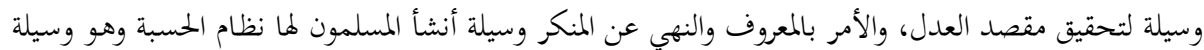

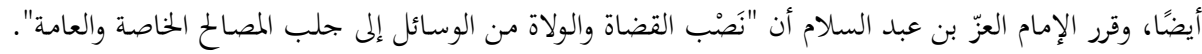
انظر

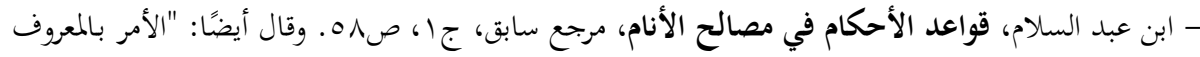

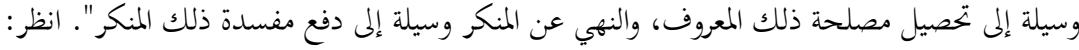

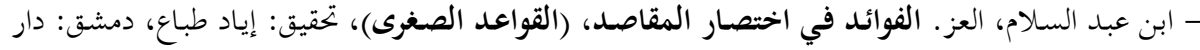

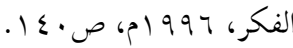

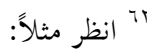

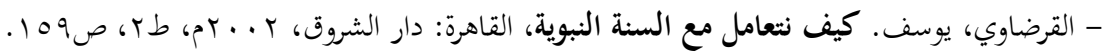

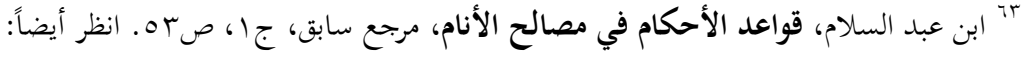

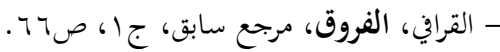

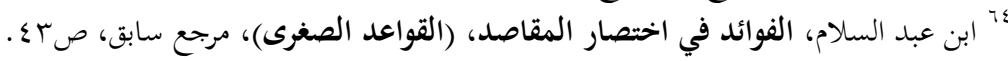




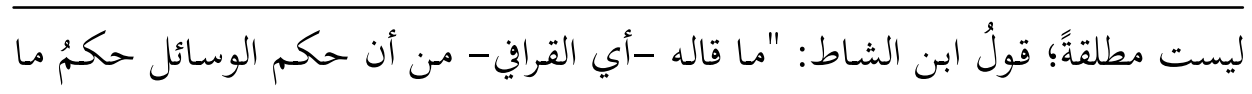

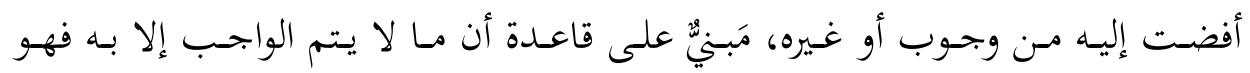

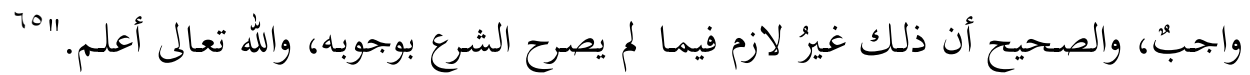

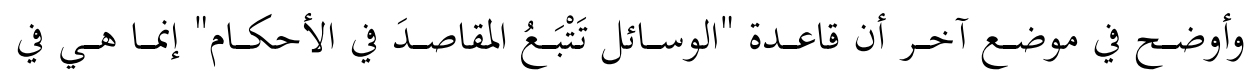
الوسائل الشرعية لا الوسائل العاديّة.

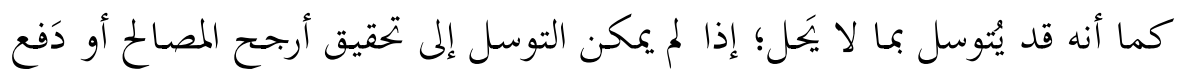

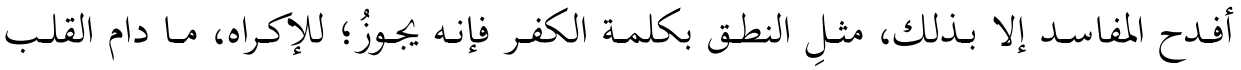

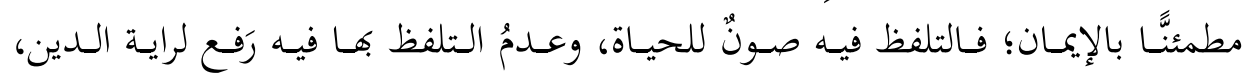

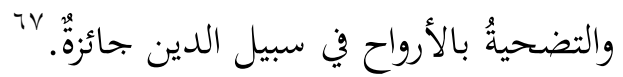
ويمكن إيضاح تَغَيُرُ الوسائل من خلال جملة أمور:

\section{أ. قواعد الوسائل الدالة على التغيُر:}

انبنى على ثبات المقاصد وتَغَيُرٌ الوسائل جملةُ قواعد: أولها: مراعاة المقاصد مقدمة على رعاية الوسائل أبدًا:

فإذا تعارضت المقاصد والوسائل وجب مراعاة المقاصد وتقديُهُا على الوسائل؛ لأن

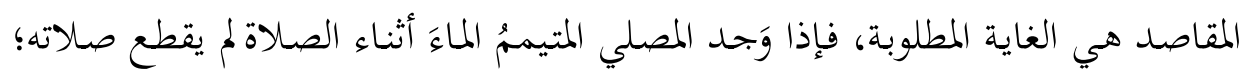
لأن الماء وسيلة عند مالك.

ثانيها: الوسائل تقوم بقيام المقاصد وتسقط بسقوطها

فإذا أمكن تحقيق المقاصد من دون الوسيلة المُعَيّنة لمُ يُتَوسَّل بها، قال الشاطبيُّ: "قد

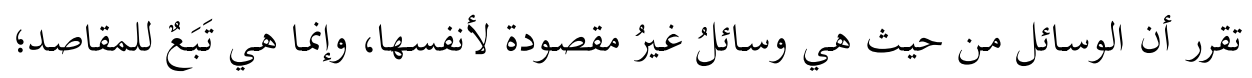
ه" ابن الشاط، أبو القاسم قاسم بن عبد الله. إدْرَار الشروق على أَنْوَاءِ الفروق، حاشية على الفروق للقرافِ مطبوعة

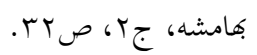

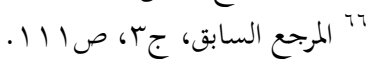

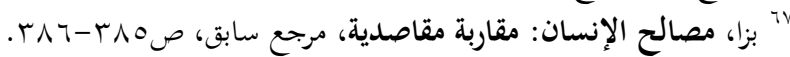

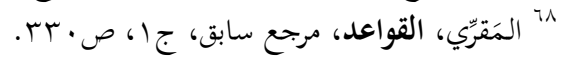


بحيـث لو سقطت المقاصـد سقطت الوسـائل، وبكيـث لـو تُوُصِّلَ إلى المقاصـد دوفهـا لم

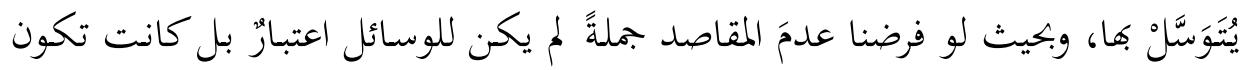
كالعبث." ومثال ذلك ضرَّبُ الصبيان على ترك الصالاة والصيام وغير ذلك من المصالح، "وإِنما جاز لكونه وسيلةً إلى مصلحة، فإذا لمُ يَحصل التأديب سقط الضربُّ...؛؛ لأن الوسائل

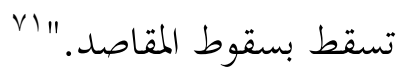

ثالثها: يُغنتَفَرَ في الوسائل ما لا يُغْتَفَرَ في المقاصد

ومدار هذه القاعدة على أن الوسائل ما دامت مقصودة لغيرها، فإنه يتم التساهل فيها بخلاف المقاصد، ومـن هذا الباب رأى الفقهاء عدم حُرمة السفر ليلة الجمعـة؛ لأن السفر ليلة الجمعة وسيلةٌ لتَرْك الجمعة، وكذلك تحريم التثليث في الوضوء عند ضِيق الوقت

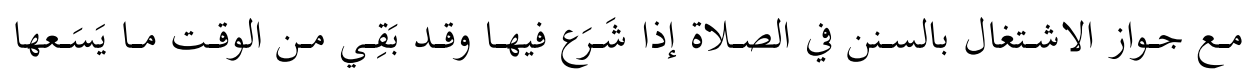
فقط.

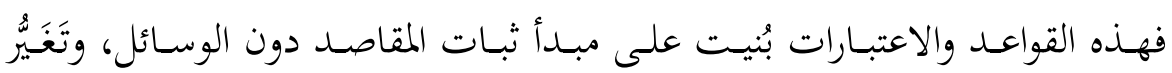

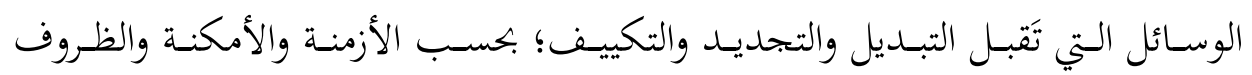
والأحوال والأعراف والقدرات والإمكانات، والوسائل كذلك يمكن أن ينوب بعضها عن بعض، ويقوم بعضها مقام بعض؛ ما دامت تحقق المقصد.

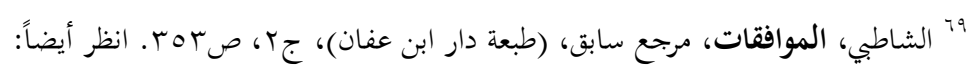

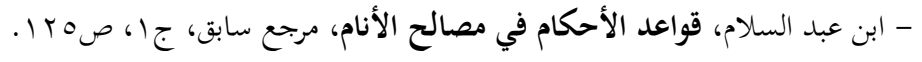

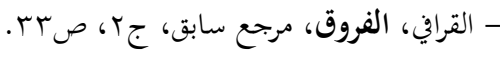

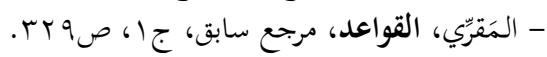

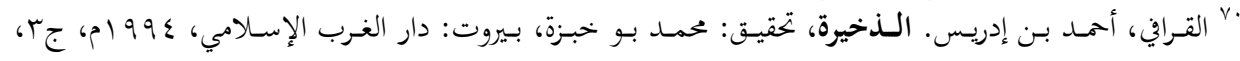
صVVIV

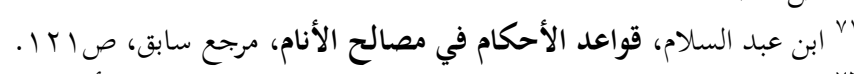

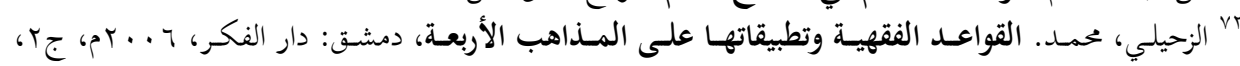




\section{ب. ضوابط تَغَيُر الوسائل المنصوصة:}

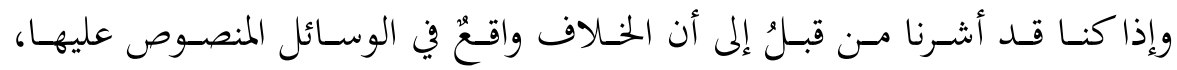

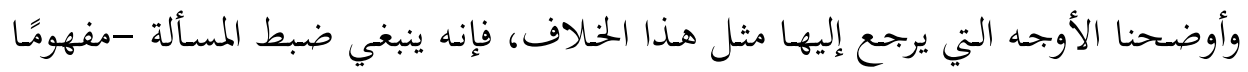

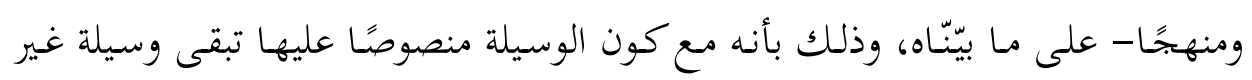

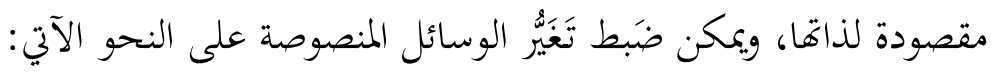

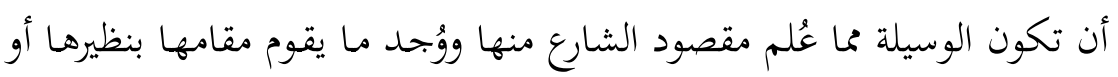

أَتَمَّم منها:

فالوسيلة المنصوصة، إذا وُجــد مـا يُعَوّضهـها مـن الوسائل فهو أولى؛ وإن لمُ يَرد بـه

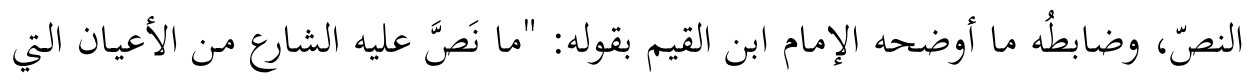

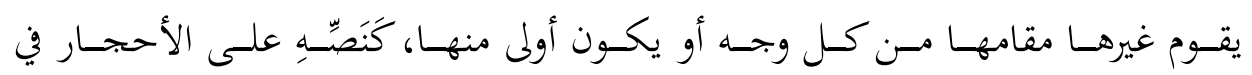

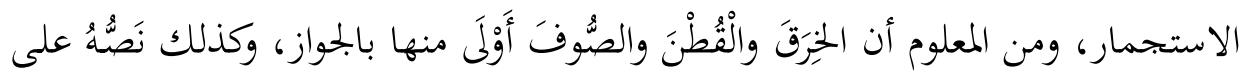

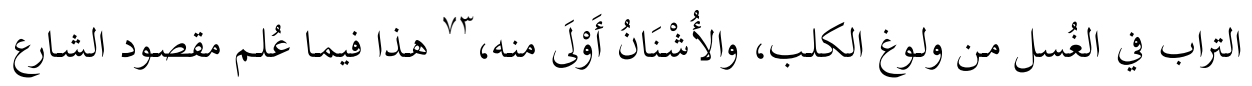

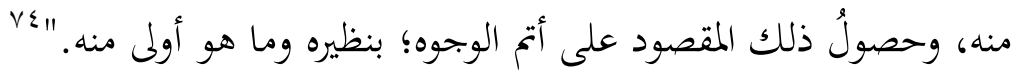

ومـن هـا البـاب أيضًا مسـائلُ مـا يسمى بـ "الطب النبوي" مـثلاً -وهي تسميةٌ

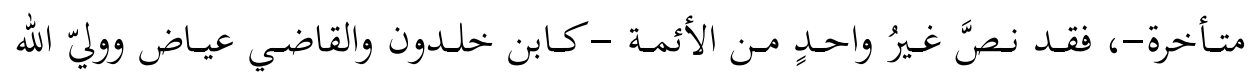

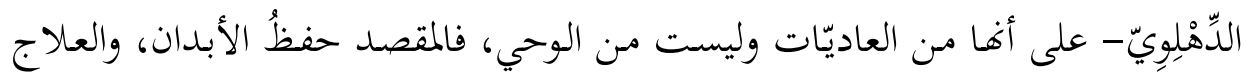

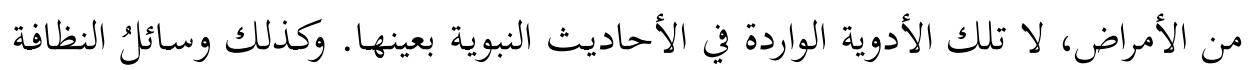

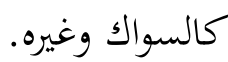

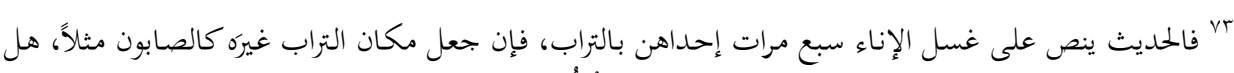

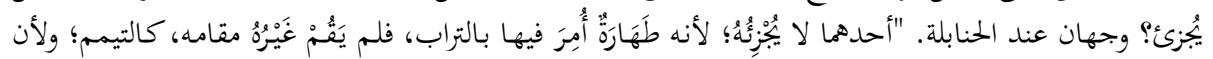

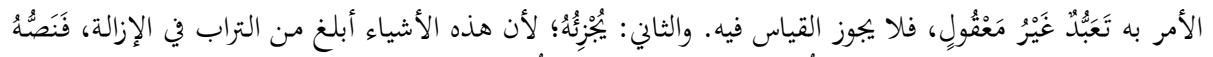

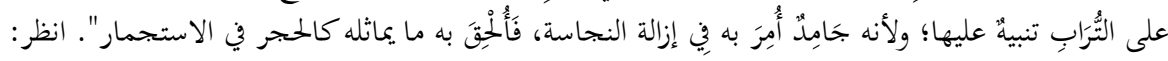

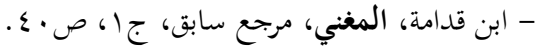

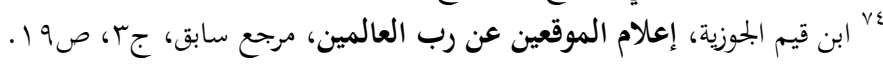


ويمكـن الاستشـهاد هنـا على هـذا الأصـل بحـديث رافع بـن خَـديج، قـال: قلـت يـا

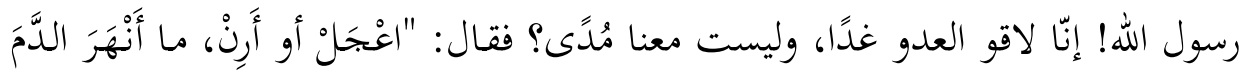

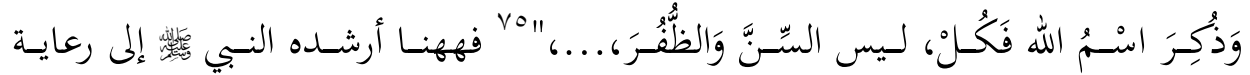

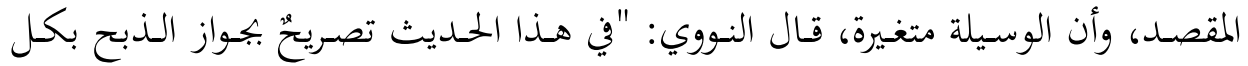

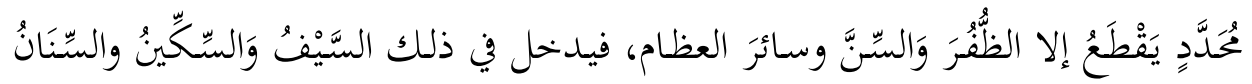

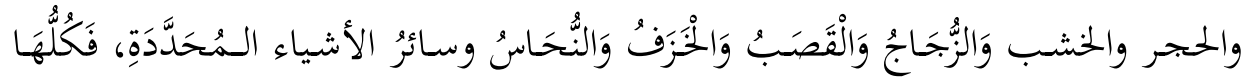

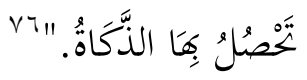

وإغفال هذا الملحظ في تَغَيُرٌ الوسيلة مع التمسك بظاهر لفظ الشارع، أو بالوصف الوارد عند التشريع يوقِع فيما يشبه أحوال أهل الظاهر، مثل ما وقع لبعض الفقهاء من

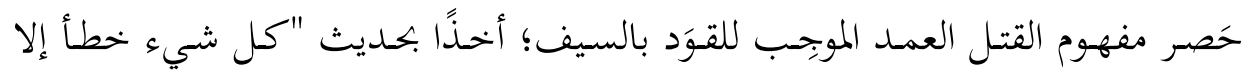

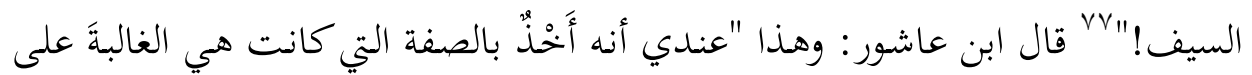
آلات القتل في الزمن الذي ورد فيه حكمُ القوَد، وهي السيف، ثم أُلحق بالسيف كلهُ آلة

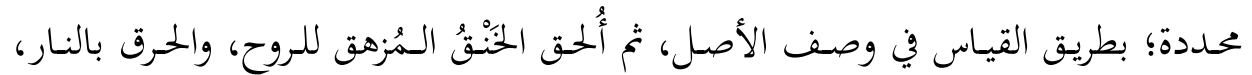
والذبح بالقصب؛ بطريق القياس أيضًا. ووُقف عند ذلك، فُنفي القصاص في القتل برمي صخرة صماء من علوِّ على جالس تحته، والقتلِ بضرب الرأس بدبوس، والإغراقِ مكتوفًا،

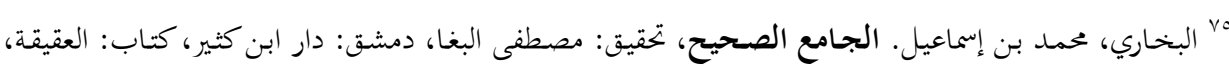

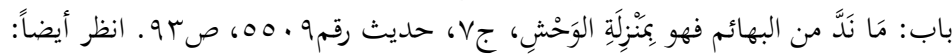

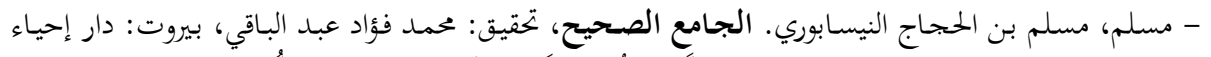

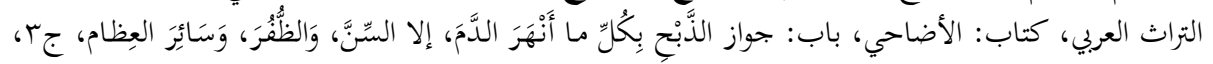

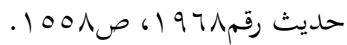

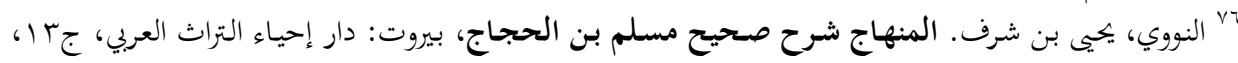
صبr

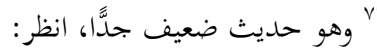

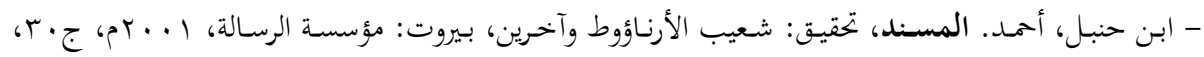

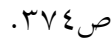

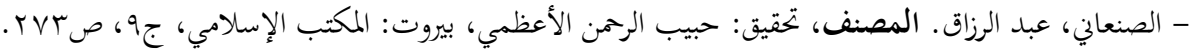

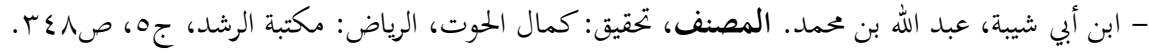




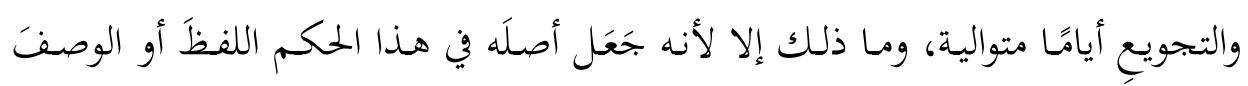
دون المقصد.

أن تكون الوسيلة المنصوصة مرتبطة بعرف أو حال أو زمان:

ومما يُحمَل على رعاية المقاصد دون الثبات على الوسائل، أن بعضها يتجدد بتطور

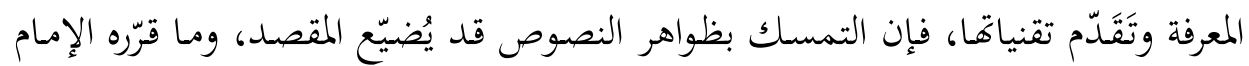

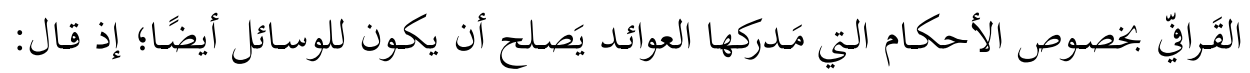

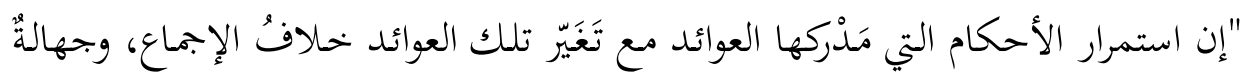

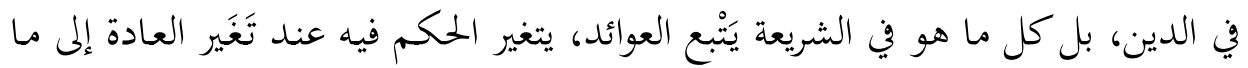
تقتضيه العادة المتجديّدة.

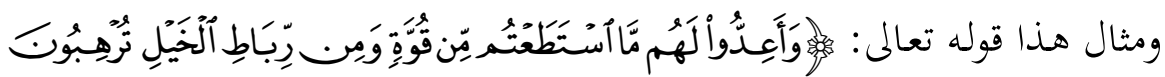

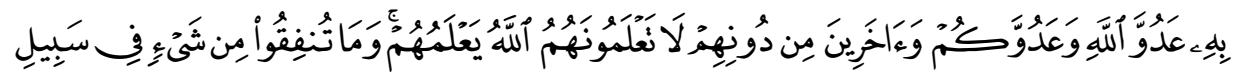

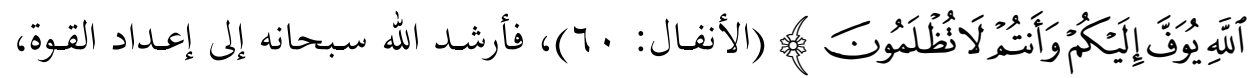
التي هي وسيلة حفظ مصالح الإسلام والمسلمين، وذكر وسيلة الخيل مـن وسائل القوة وهي متغيرة، فلو اقتُصر عليها لَفَات المقصد بالكلية؛ بالرغم من وجود أحاديث كثيرة عن العن

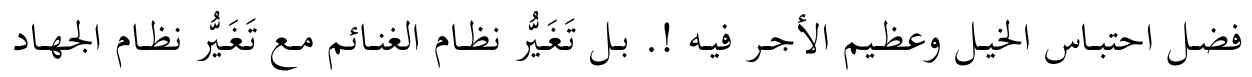
ووسائله؛ فقد كان الرجل قديمًا يشتري سلاحه من ماله الخناص، ويتعهد صيانته، ولذلك لك كان الحكم يفترق في الغنيمة بين الراجِل والفارس، ولكن أصبح للدول اليوم جيوش يوكَل إليها تلك المهمة، وتتولى الدول رعايتها وتوفير كل السبل اللازمة لها. •^

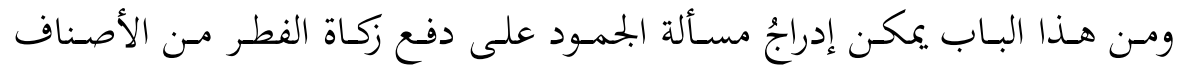

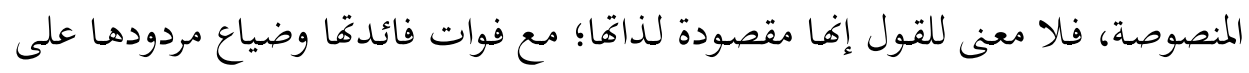

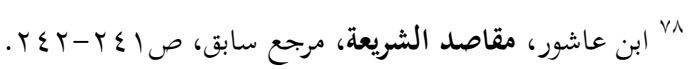

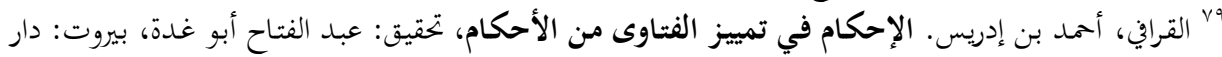

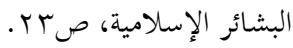

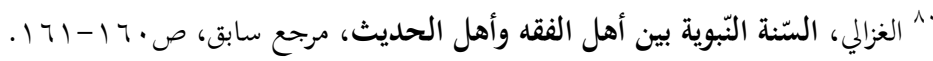




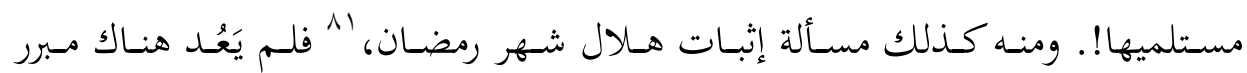
للإصرار على رؤيته بالعين المحردة مع تَقَّدم الوسائل العلمية وتطورها، فالقول: إن الإسلام

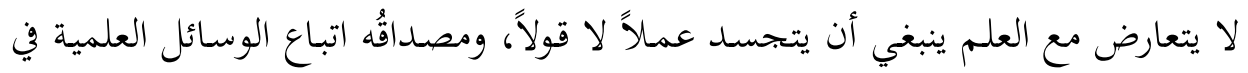

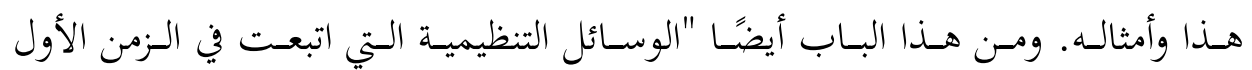

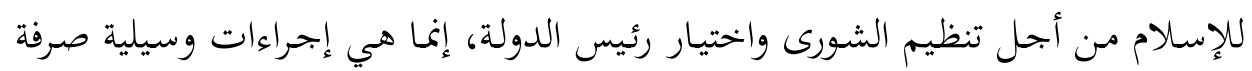

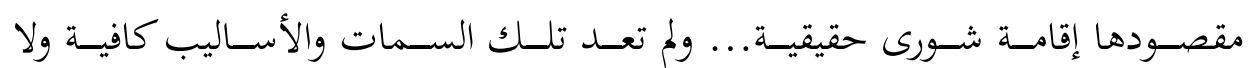
مالائمة.

فالتمسـك بـالظواهر قــ يُفسوّت الأصـلح مـن الوسـائل لتحقيـق المقصـــ لأن تطـور

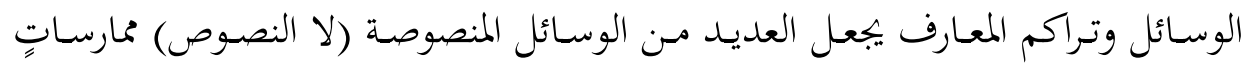

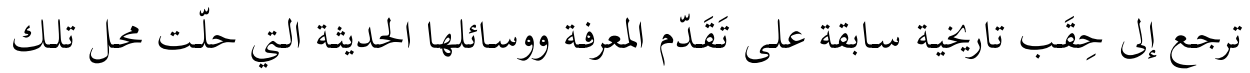

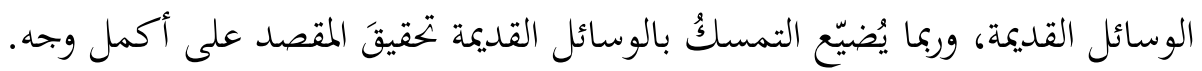
العقود تصحُّ بكل ما دلّ على مقصودها:

ومما يدخل في الوسائل ما يفيد معنَى "كصيغ العقود وألفاظ الواقفين في كوها وسائل

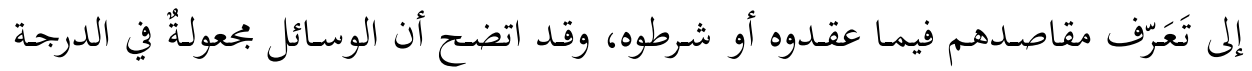

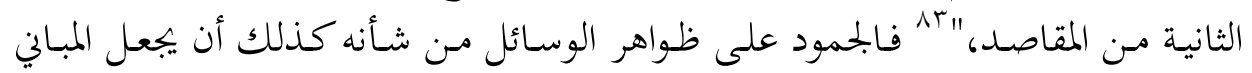

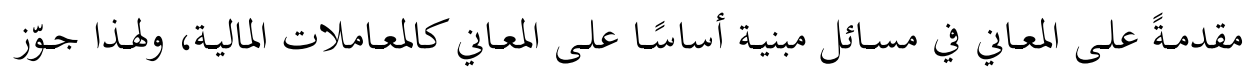

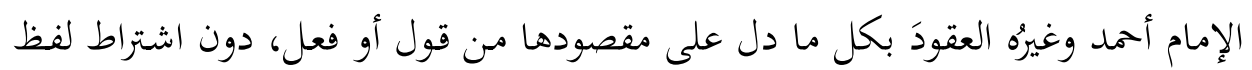

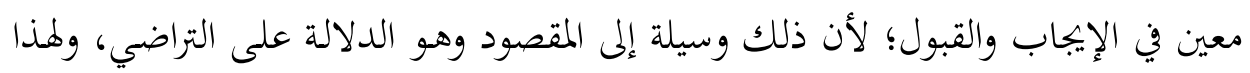

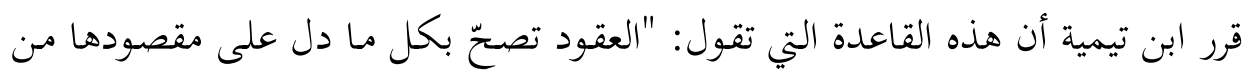

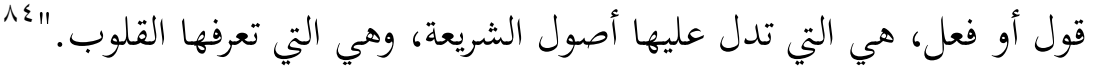

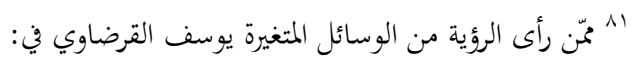

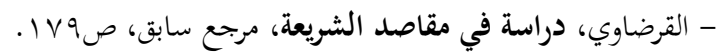

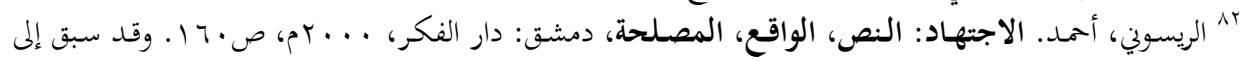

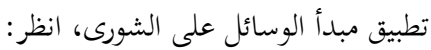

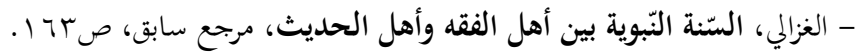

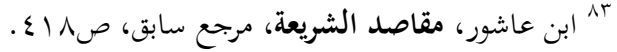

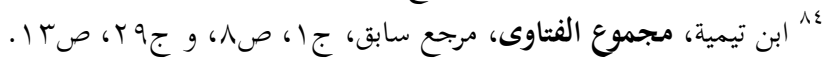


ومما يدخل في هذا الباب: "استعمال بعض صيغ العقود في غير ما وُضعت له؛ إذا

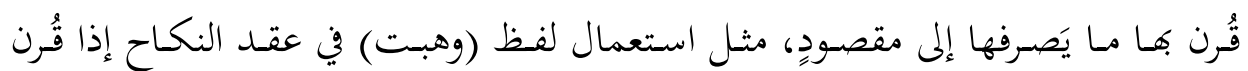

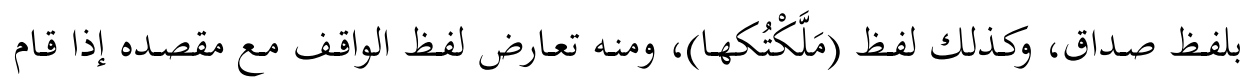
على مقصـده دليـلو غـيرٌ لفظه، وكـان لفظه يخـالف ذلكـ، ولـذلك قـال الفقهـاء: إذا

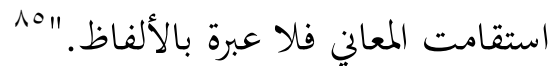
أن تَعْرَى الوسيلة عن دليلٍ بِيْرَدها للمعنى التعبدي: فإنان ركنَ الوسائل المنصوصة المتغيّرة ألا يقوم فيها معنى التعبـد للذاتها، ومـن تَّهُ كان التَغَيُّر قائمًا على أساس ردن التعليل، والأصل في هذا أمران: الأول: في مفهوم التعبـدي والتعليلي، فقـد قرر الإمـام العزّ أن المشـروعات ضـربان:

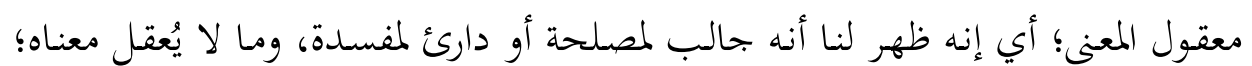

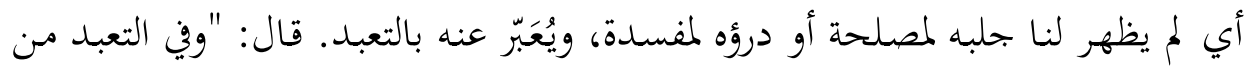

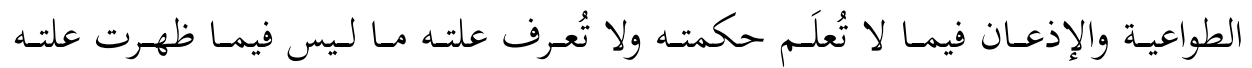

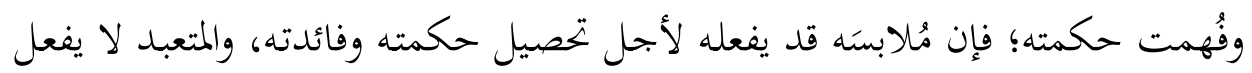

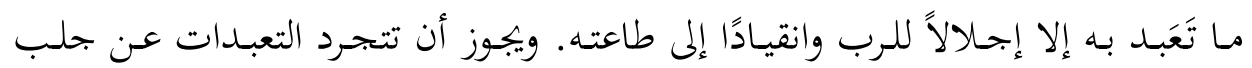

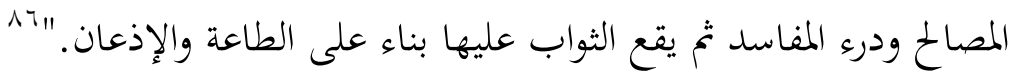
الثـاني: في بجـال التعبـد والتعليـل، فقـــ قرر الإمـام الشـاطبي أن الأصـل في العبـادات

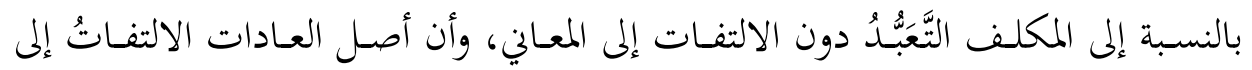

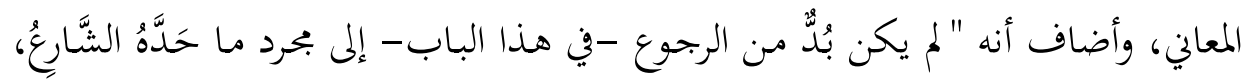

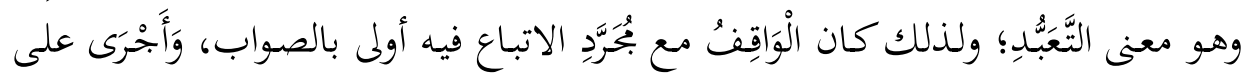

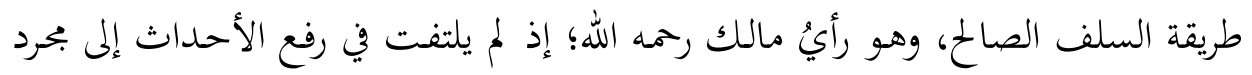
النظافة حتى اشترط النية والماءَ المطلق، وإن حصلت النظافة بغير ذلك، وامتنع مـ إقامة

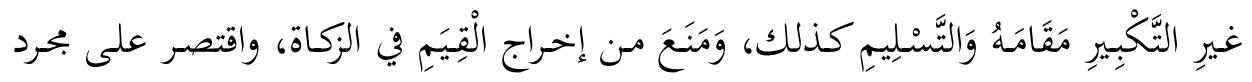

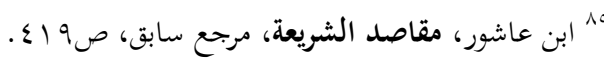

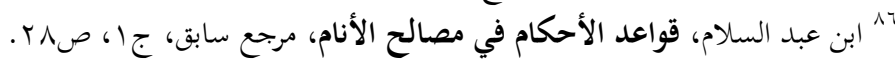




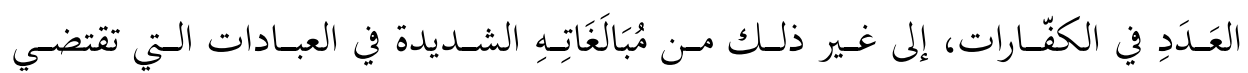
الاقتصارَ على محض الْمَنصُوصِِ عليه أو ما مَاثَلَه..

ونحن هنـا إنما نقرر الأصل فقط، ونخرّج عليه بعض الخـلاف الفقهي القـديم؟ مـن أجـل التفسير فقـط، لا لأجـل الجريـان على تطبيقاته بالموافقـة والتأييـد، فبإن مـن شـأن منهجيـة الوسـائل أن تتجـاوز مثل هذا الفهم في مثل هذه التطبيقـات التي نراهـا معقولة أنس

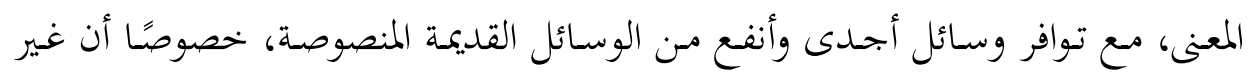

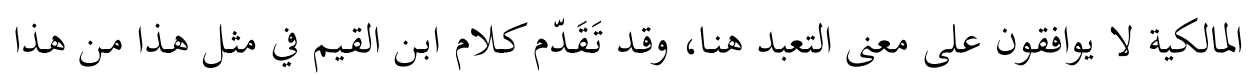
البحث.

ويمكـن التمثيـل أيضًا في هـذا البـاب بالمسـألة التي تـردد فيهـا الإمـام العـزّ وجعلهـا

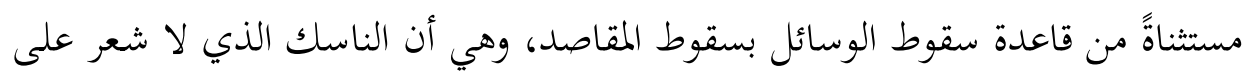

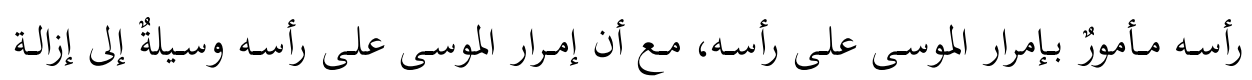

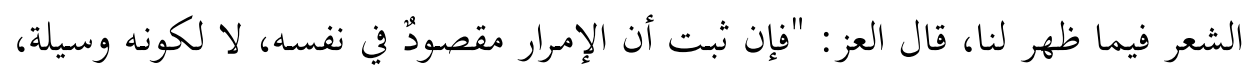

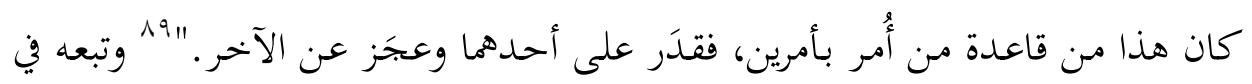

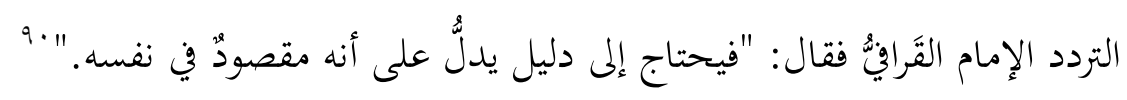

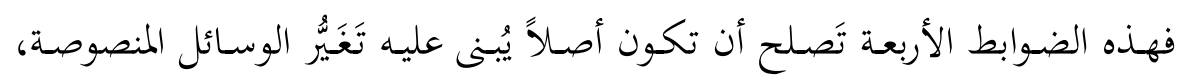

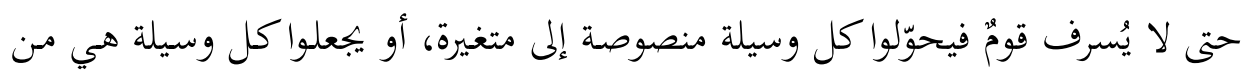
قبيل التعبدي الواجب الامتثال له.

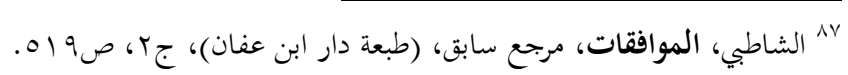

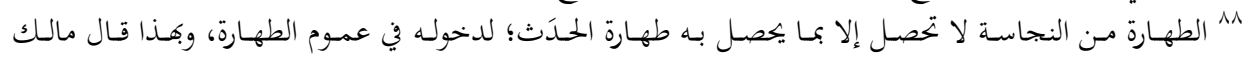

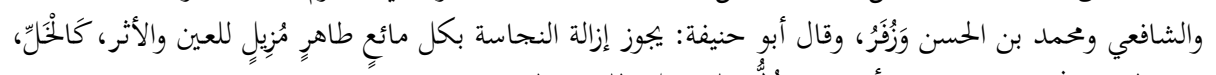

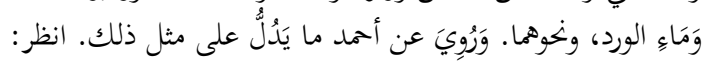

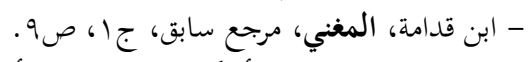

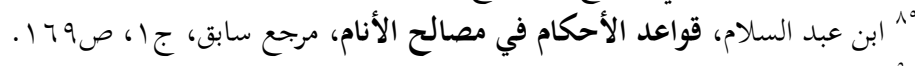

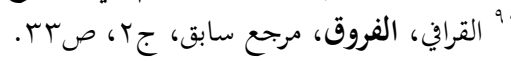


هكذا تتضـح أهميـة منهجيـة المقاصــ والوسـائل في فقـه الشـريعة نصَّـا وتنـيلاً؛ لأن غياهـا مـن شأنه أن يضيّع كثيراً مـن المصالح، سواء في النظر إلى النصوص الشرعية أم في تطبيق الأحكام الفقهية وتنزيلها على الواقع، وهي منهجية من شأها أن تعصم الفقيه من

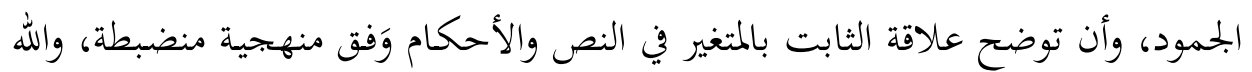
تعالى أعلم.

\section{خاتمة:}

خلَص البحث إلى أنَّ "الوسائل" تصلُح أن تصاغ في نظرية يمكن أن تسمى "نظرية

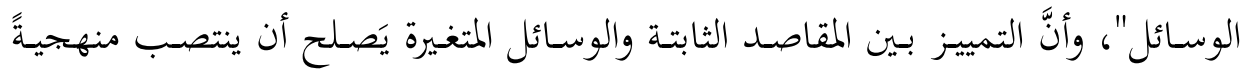
صالحةً للاجتهاد الفقهي بحيث يفرّق بين الثابت والمتغير من الوسائل حتى لا يتم الجمود

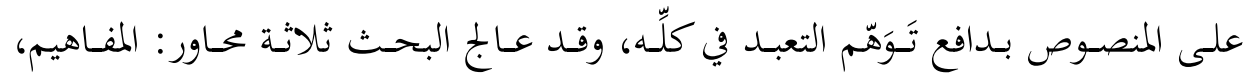
وتاريخ المنهجية في العقل الفقهي، وأبعاد المنهجية المقترحة.

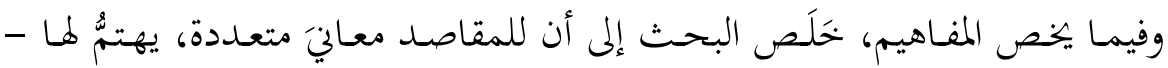
جميعًا- الأصوليون والفقهاء، ولكنّ وظائف معرفتها تتفاوت فيما بينها، فتُطلق ويُراد بها

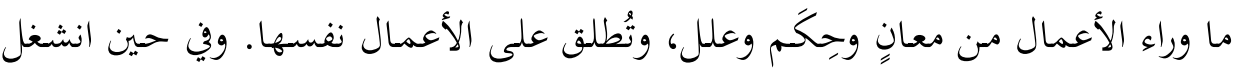

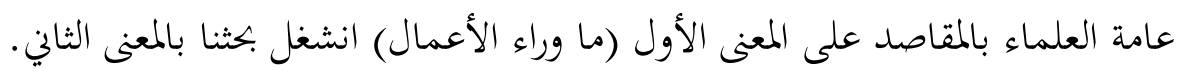
وموضوع الوسائل المتغيرة هو ممـا يقع فيه الغلط، ومنشـأ الغلط عـدمُ تحرير المفهوم

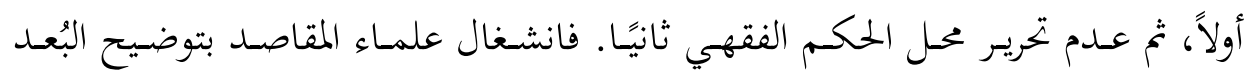

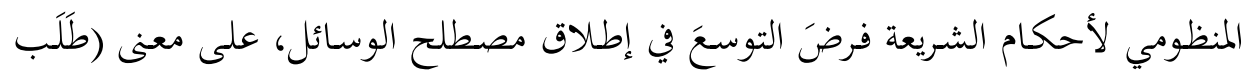
أمرٍِ لأمرِ آخر)، على حين أن البُعد العملي الفقهي المتعلق بجهة معرفة الأحكام وفقـه

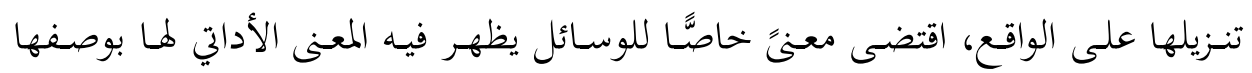

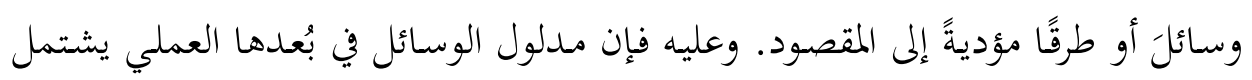

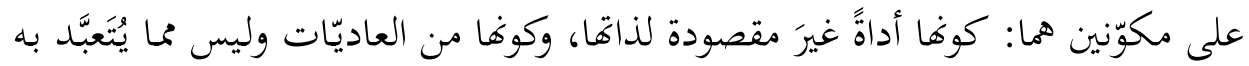


ومبنى مسألة الوسائل على تقرير مسألة المقاصد، ومبنى مسألة المقاصد على فكرة

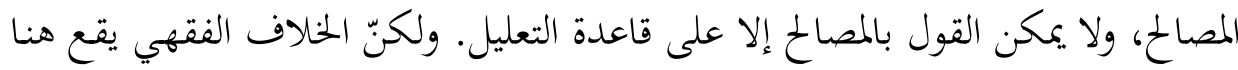

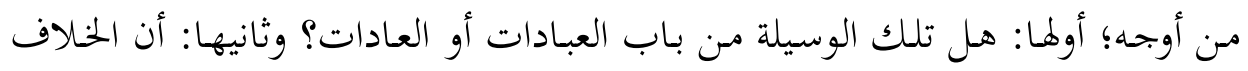

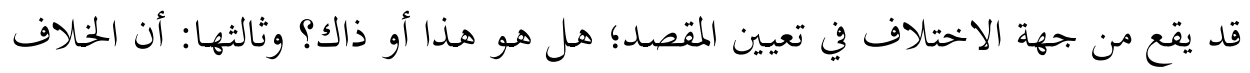

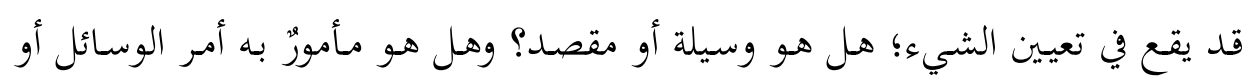

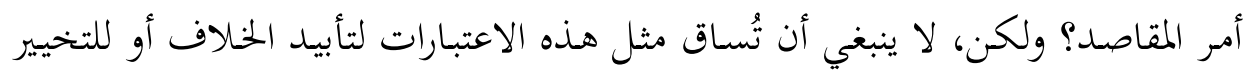

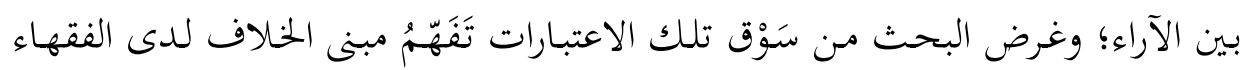

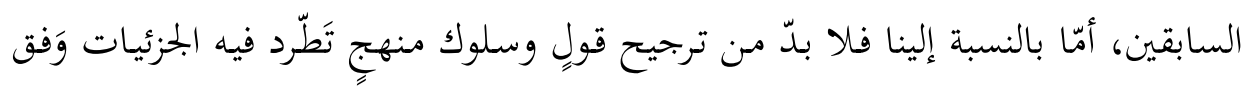

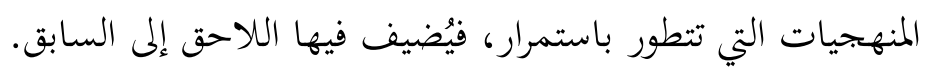

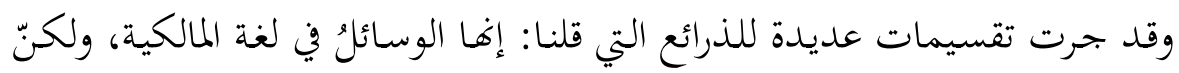

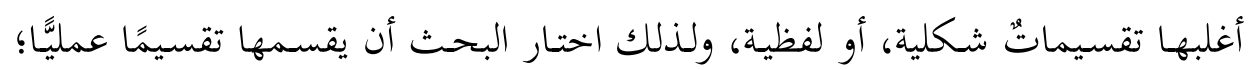

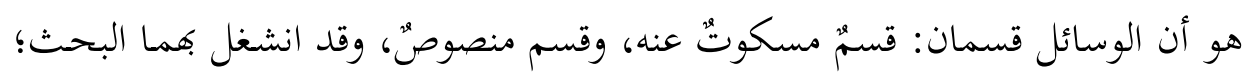

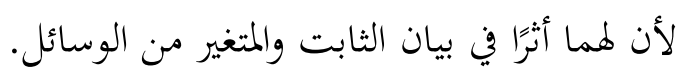
بنى البحث القسمَ المسكوت عنه على قاعدة: "كلُّ دليل شرعي ثبت في الكتاب

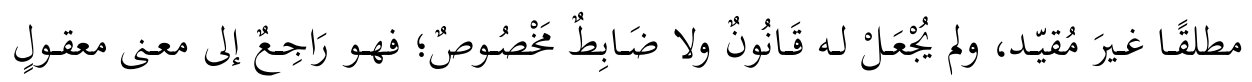

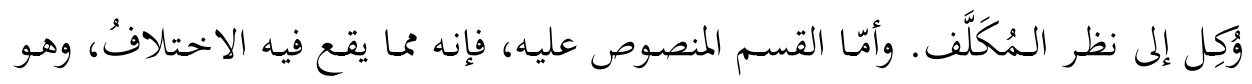

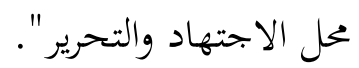

وحَرَص البحث على إيضاح تَغَيُرُ الوسائل المنصوصة من خلال جملة أمور: أوها: قواعد الوسائل الدالة على التغيُرُ، كرعاية المقاصد مقدمة على رعاية الوسائل

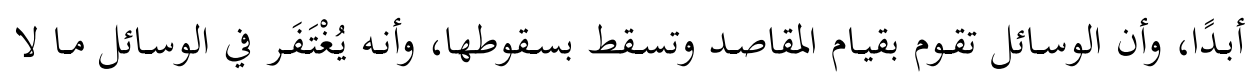
يُغْتَفَرَ في المقاصد. و تون 
وثانيها: تَقَدّم البحث في معالمته، فوضع ضوابط لتَغَيّر الوسائل المنصوصة، حصرها

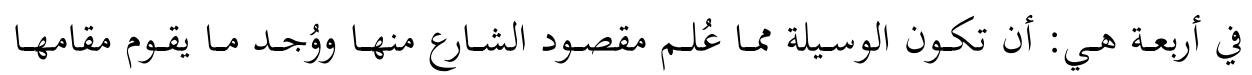

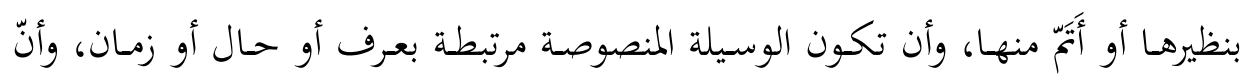

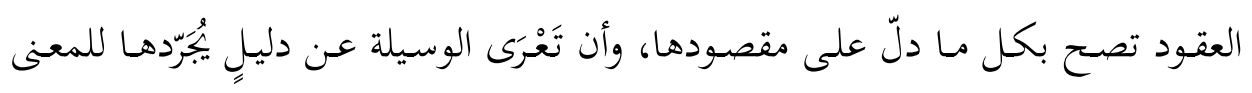

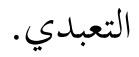

فهذه الضوابط الأربعة تَصلح أن تكون أصلاً يُبنى عليه تَغَيُّر الوسائل المنصوصة،

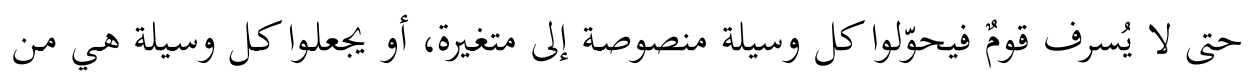
قبيل التعبدي الواجب الامتثال له. 